ISAC BARCELOS PEREIRA DE SOUZA

Equipes conjuntas de investigação na cooperação jurídica internacional em matéria penal: requisitos de formação à luz da eficiência e do garantismo

Dissertação de Mestrado

Orientador: Professor Dr. Marcos Alexandre Coelho Zilli

UNIVERSIDADE DE SÃO PAULO

FACULDADE DE DIREITO

São Paulo-SP

2017 
ISAC BARCELOS PEREIRA DE SOUZA

\section{Equipes conjuntas de investigação na cooperação jurídica internacional em matéria penal: requisitos de formação à luz da eficiência e do garantismo}

Dissertação apresentada à Banca Examinadora do Programa de Pós-Graduação em Direito, da Faculdade de Direito da Universidade de São Paulo, como exigência parcial para a obtenção do título de Mestre em Direito, na área de concentração de Direito Processual, sob a orientação do Professor Dr. Marcos Alexandre Coelho Zilli.

UNIVERSIDADE DE SÃO PAULO

FACULDADE DE DIREITO

São Paulo-SP 
Souza, Isac Barcelos Pereira de

Equipes conjuntas de investigação na cooperação jurídica internacional em matéria penal: requisitos de formação à luz da eficiência e do garantismo / Isac Barcelos Pereira de Souza ; orientador Marcos Alexandre Coelho Zilli -- São Paulo, 2017.

$258 \mathrm{f}$.

Dissertação (Mestrado - Programa de Pós-Graduação em Direito Processual) - Faculdade de Direito, Universidade de São Paulo, 2017.

1. Direito processual penal. 2. Cooperação jurídica internacional em matéria penal. 3. Investigação criminal. 4. Eficiência e garantismo. 5. Crime transnacional. I. Zilli, Marcos Alexandre Coelho, orient. II. Título. 
Nome: Isac Barcelos Pereira de Souza

Título: Equipes conjuntas de investigação na cooperação jurídica internacional em matéria penal: requisitos de formação à luz da eficiência e do garantismo

Dissertação apresentada à Faculdade de Direito da Universidade de São Paulo como exigência parcial para obtenção do título de Mestre em Direito.

Aprovado em:

Banca Examinadora

Prof. Dr. Instituição:

Julgamento: Assinatura:

Prof. Dr. Instituição:

Julgamento: Assinatura:

Prof. Dr. Instituição:

Julgamento: Assinatura: 
Às pequenas Gynna e Ana Helena, que enchem a nossa família de alegrias. 


\section{AGRADECIMENTOS}

A Deus, por tudo.

Aos meus pais Zelia e José Roberto, por todo amor, sacrifício e incentivo para que eu pudesse alcançar os meus objetivos. À minha mãe, agradeço toda a dedicação e cuidado, ainda hoje, e mesmo a distância. Sou grato, também, por haver me ensinado o valor do estudo, da leitura e dos livros.

À minha irmã Roberta, exemplo de dedicação e seriedade acadêmica, por toda a nossa amizade, seu apoio constante e, principalmente, pelo grande presente que proporcionou à nossa família: Ana Helena.

Ao Prof. Dr. Marcos Alexandre Coelho Zilli, por ter confiado no meu projeto de pesquisa, aceitando-me como seu orientando e, consequentemente, por me ter aberto as portas da Faculdade de Direito da Universidade de São Paulo.

Ao Prof. Titular Antonio Scarance Fernandes e ao Prof. Fabio Ramazzini Bechara, por todas as sugestões e contribuições no exame de qualificação.

Ao Prof. Associado Gustavo Henrique Righi Ivahy Badaró, pelo conhecimento compartilhado nas disciplinas da pós-graduação e por sua grande disponibilidade para ensinar.

Ao Prof. Titular Paulo Borba Casella pelos valiosos ensinamentos nas aulas da pós-graduação, fundamentais para a elaboração de parte deste trabalho.

Ao Prof. Associado André de Carvalho Ramos, pelas precisas contribuições e pelos vários esclarecimentos ao longo da redação desta dissertação.

Ao amigo Prof. Antonio do Passo Cabral, que em diversas etapas da elaboração deste trabalho apresentou valiosas críticas e inúmeras sugestões. Meu muito obrigado pelo diálogo constante e pelos generosos ensinamentos. 
À Luiza Cristina Fonseca Frischeisen, por nossa amizade e por todo o incentivo ao meu desenvolvimento acadêmico e profissional.

Ao amigo Marcelo Vieira, pela ajuda desde a preparação para a prova de ingresso na Pós-graduação até a elaboração desta dissertação, mas principalmente pelo privilégio de sua amizade.

Ao amigo Henrique Castilho, pelo incentivo e colaboração à época das provas de ingresso na Pós-graduação e ao longo de todo o curso.

Ao amigo Victor Valarini, pela atenta leitura desde as primeiras versões deste trabalho e pela nossa amizade.

Aos amigos Danilo Lobato; pelo auxílio com algumas questões afetas ao Direito Penal e à Criminologia; e Tatiana Jogaib, pela cuidadosa leitura do trabalho.

Aos colegas e amigos Vladimir Aras e Douglas Fischer, que, em relação à diversas partes do trabalho, contribuíram com excelentes críticas e ponderações. Muito obrigado, igualmente, a Alexandre Senra e Silvio Pettengill, pelo constante debate e pela fraterna amizade.

Aos amigos Daniel Fontenele, Ellen Chaves, André Bueno, Ângelo Villela, Laura Tessler e Rodrigo Azevedo, pela ajuda para que eu pudesse compatibilizar a Pós-graduação e os trabalhos na Procuradoria da República em Guarulhos.

À Chefe da Divisão de Biblioteca da Procuradoria da República de São Paulo, Maristela Simon Szpeiter Lopes de Oliveira, pelo auxílio em parte da pesquisa bibliográfica.

Ao Ministério Público Federal, pelo incentivo à capacitação de seus membros e apoio na etapa final de redação deste estudo. 


\section{RESUMO}

SOUZA, Isac Barcelos Pereira de. Equipes conjuntas de investigação na cooperação jurídica internacional em matéria penal: requisitos de formação à luz da eficiência e do garantismo. 2017. 258 p. Mestrado - Faculdade de Direito, Universidade de São Paulo, São Paulo, 2017.

O presente estudo tem por escopo analisar as Equipes Conjuntas de Investigação (ECls) e os seus respectivos requisitos de formação, ou seja, aqueles elementos considerados indispensáveis para a constituição válida de uma ECI. Em apertada síntese, as ECls podem ser definidas como os grupos formados por agentes designados por dois ou mais Estados, para a realização de uma investigação criminal determinada, de maneira unida e coordenada, e em um prazo certo. Tratase de instrumento de cooperação jurídica internacional que, desenvolvido pela via direta, permite, sob certas condições, atuações transnacionais de seus membros e trâmite direto de informações e documentos entre os integrantes do grupo. No Brasil, a formação das ECls é admitida com base nas Convenções da Organização das Nações Unidas (ONU) de Viena de 1988, Palermo de 2000 e Mérida de 2003, bem como na Lei no 13.344/2016. A análise das ECls neste trabalho funda-se na premissa da necessária conformação entre os interesses do Estado na persecução penal eficiente, com o imprescindível respeito a todos os direitos e garantias assegurados aos investigados.

Palavras-chave: Direito processual penal. Cooperação jurídica internacional em matéria penal. Investigação criminal. Eficiência e garantismo. Crime transnacional. 


\begin{abstract}
SOUZA, Isac Barcelos Pereira de. Joint investigation teams and mutual legal assistance in criminal matters: formation requirements in the light of efficiency and guarantees. 2017. 258 p. Master - Faculty of Law, University of São Paulo, São Paulo, 2017.

This study analyses the Joint Investigation Teams (JITS) and their formation requirements. These requirements must be fulfilled for the valid formation of a JIT. The JITs can be defined as groups formed by agents designated by two or more States to conduct a specific criminal investigation, in a united and coordinated way, and for a certain period of time. It is an instrument of mutual legal assistance which allows, under certain conditions, transnational actions by its members and direct exchange of information and documents among the members of the group. In Brazil, the formation of JITs is allowed based on United Nations (UN) Conventions of Vienna of 1988, Palermo of 2000 and Merida of 2003, as well as on Brazilian Federal Law no. 13.344/2016. The analysis of the JITs in this study supposes the necessary balance between the interests of the State and the efficiency of the criminal prosecution, with the necessary respect to all rights and guarantees secured to the investigated persons.
\end{abstract}

Key words: Criminal procedure. Mutual legal assistance in criminal matters. Criminal investigation. Efficiency and guarantees. Transnational crime. 


\section{LISTA DE ABREVIATURAS E SIGLAS}

ADI Ação Direta de Inconstitucionalidade

AgR Agravo Regimental

Art. Artigo

Benelux Bélgica, Holanda e Luxemburgo

BESTs Border Enforcement Security Taskforces

CEDH Corte Europeia de Direitos Humanos

Comjib Conferência dos Ministros da Justiça dos Países Iberoamericanos (Conferencia de Ministros de Justicia de los Países Ibeoramericanos)

CNJ Conselho Nacional de Justiça

COE Conselho da Europa (Council of Europe)

Coord. Coordenador(a)

Coords. Coordenadores(as)

CP Código Penal

CPC Código de Processo Civil

CPIs Comissões Parlamentares de Inquérito

CPP Código de Processo Penal

CR/1988 Constituição da República de 1988

Dir. Directores

DJ Diário da Justiça 
DJe Diário da Justiça Eletrônico

Doc. Documento

EC Emenda Constitucional

ECl Equipe Conjunta de Investigação/Equipa de Investigação Conjunta

ECls Equipes Conjuntas de Investigação/Equipos Conjuntos de Investigación

ECHR European Court of Human Rights

Ed. Edição/Editor

ESMPU Escola Superior do Ministério Público da União

EU European Union

EUA $\quad$ Estados Unidos da América

Eurojust Unidade Europeia de Cooperação Judiciária (European Union's Judicial Cooperation Unit)

Europol Serviço Europeu de Polícia (European Union's Law Enforcement Agency)

EWG Informal Expert Working Group

FATF $\quad$ Financial Action Task Force

FMI Fundo Monetário Internacional

GAFI Grupo de Ação Financeira

G-7 Grupo dos 7

HC Habeas Corpus 
IBETs Integrated Border Enforcement Teams

ILOR International Letter of Request

Inq. Inquérito

JAI Conselho de Justiça e Assuntos Internos

JHA Justice and Home Affairs Council

JIT Joint Investigation Teams

Mercosul Mercado Comum do Sul

Mercosur Mercado Común del Sur

Min. Ministro

MONUSCO Mission de L'Organisation des Nations Unies pour la Stabilisation en République Démocratique du Cong

№ $\quad$ Número

OAS Organization of American States

OEA Organização dos Estados Americanos

OLAF Organismo Europeu de Luta Antifraude (European Anti-Fraud Office ou Office Européen de Lutte Antifraude)

ONU Organização das Nações Unidas

Org. Organizador(a)

P. Página

PL $\quad$ Projeto de Lei

REMJA-X Décima Reunião de Ministros da Justiça ou de Outros Ministros ou Procuradores-Gerais das Américas 
RMS Recurso em Mandado de Segurança

RS Rio Grande do Sul

SICA Sistema de Integração Centro-americano (Sistema de la Integración Centroamericana)

STF Supremo Tribunal Federal

STJ Superior Tribunal de Justiça

TPI Tribunal Penal Internacional

UE União Europeia

UN United Nations

US United States

UNCAC Convenção das Nações Unidas contra a Corrupção (United Nations Convention against Corruption)

UNODC Escritório das Nações Unidas sobre Drogas e Crime (United Nations Office on Drugs and Crime)

UNTOC Convenção das Nações Unidas contra o Crime Organizado Transnacional (United Nations Convention against Transnational Organized Crime) 


\section{SUMÁRIO}

INTRODUÇÃO

CAPÍTULO 1 - GLOBALIZAÇÃO, CRIME TRANSNACIONAL, COOPERAÇÃO JURÍDICA INTERNACIONAL E EFICIÊNCIA NA INVESTIGAÇÃO CRIMINAL.. 33

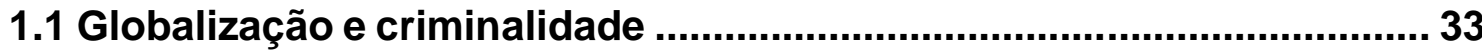

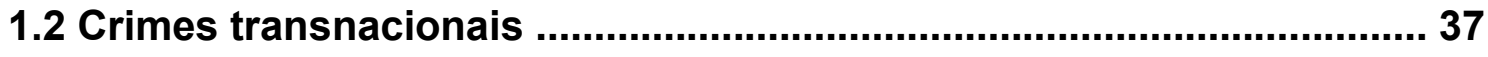

1.3 Cooperação jurídica internacional .......................................................... 43

1.4 Os desafios da investigação da criminalidade transnacional ............... 46

1.5 Eficiência e garantismo no processo penal .........................................50

1.6 Cooperação jurídica internacional à luz da eficiência e do

garantismo 52

CAPÍTULO 2 - EQUIPES CONJUNTAS DE INVESTIGAÇÃO: DESENVOLVIMENTO HISTÓRICO, CONCEITO E NATUREZA JURÍDICA ....... 57

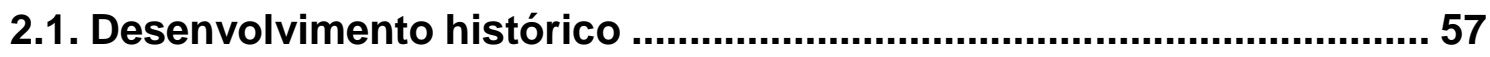

2.1.1 As primeiras experiências: a cooperação internacional entre forças policiais e algumas iniciativas de atuação direta transnacional ............... 57

2.1.2 As normatizações internacionais: das Equipes Conjuntas às Equipes

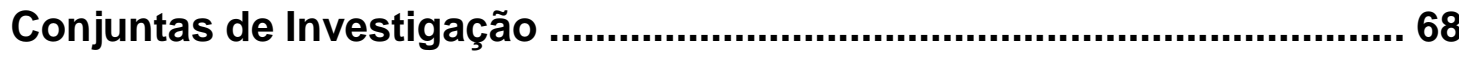

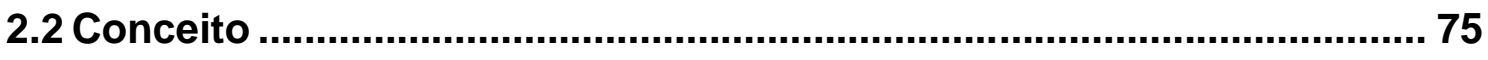

2.2.1 As investigações conjuntas em sentido lato ................................... 75

2.2.2 0 conceito de Equipes Conjuntas de Investigação .......................... 81

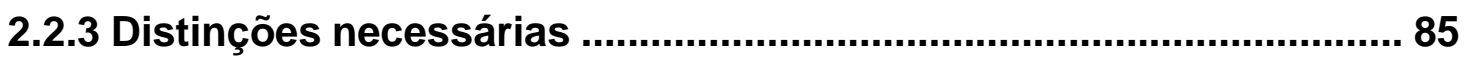

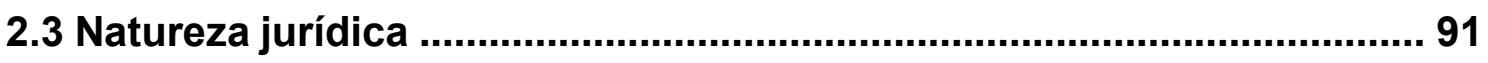

2.3.1 Instrumento de cooperação internacional policial ou jurídica? ...... 92 
2.3.2 As ECls como instrumento de cooperação jurídica internacional pela via do contato direto ................................................................................ 93

2.4 As vantagens operacionais da utilização de uma $\mathrm{ECl}$............................ 99

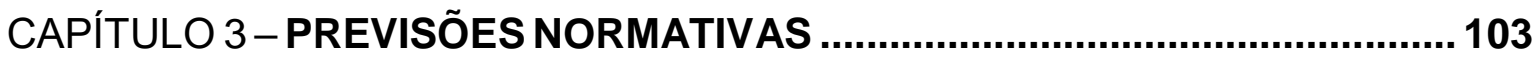

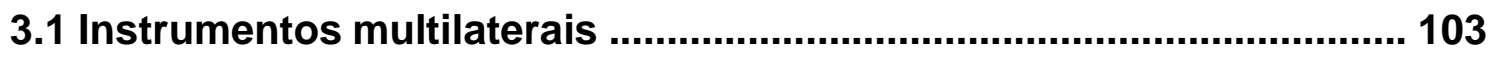

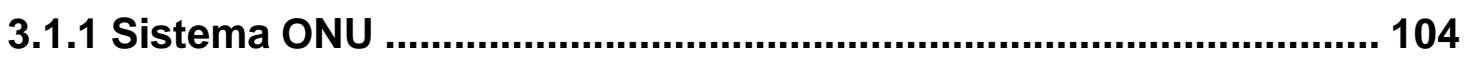

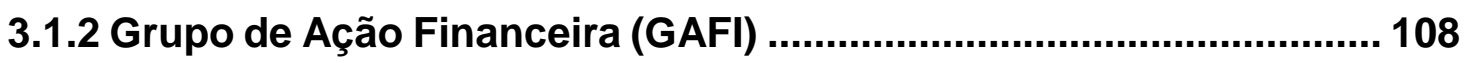

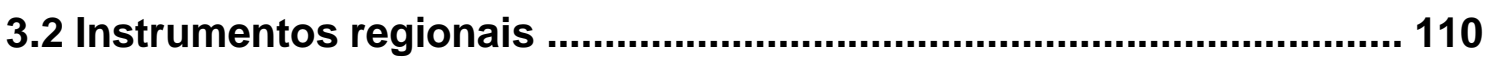

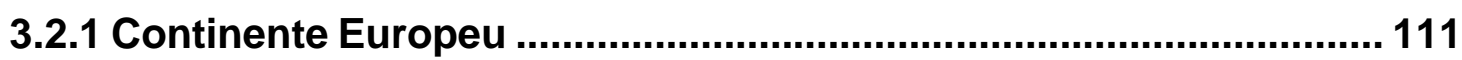

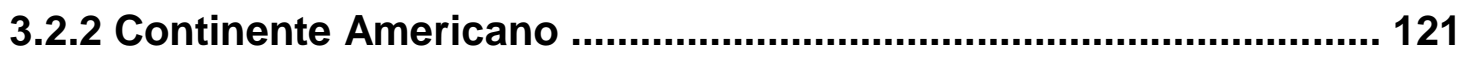

3.3 Legislações estrangeiras: panorama geral .......................................... 128

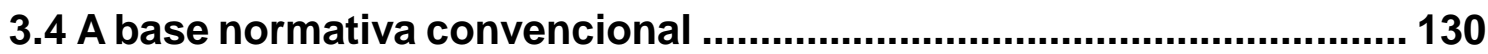

CAPÍTULO 4 - REQUISITOS DE FORMAÇÃO DAS ECIS À LUZ DA EFICIÊNCIA

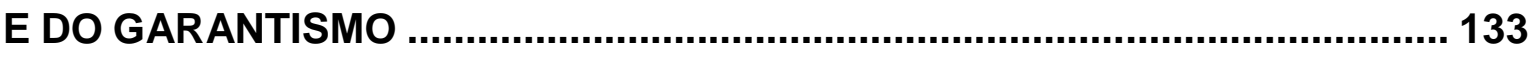

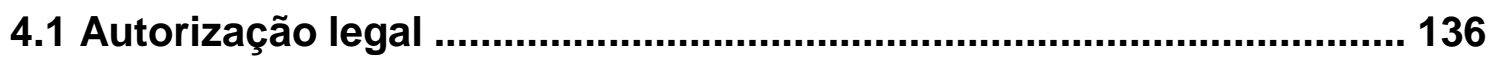

4.2 Consentimento das partes: a comunhão de vontades ......................... 149

4.2.1 Considerações iniciais: direitos e deveres dos Estados na ordem

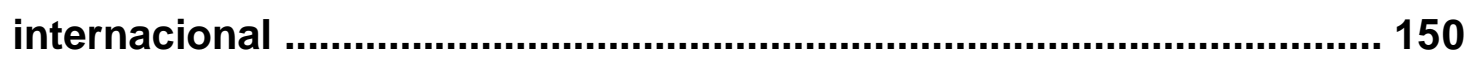

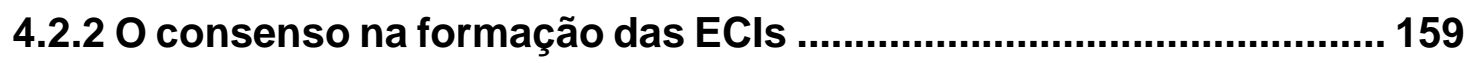

4.3 Investigação preliminar de crime transnacional determinado .............. 165

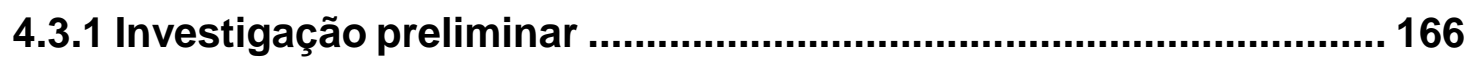

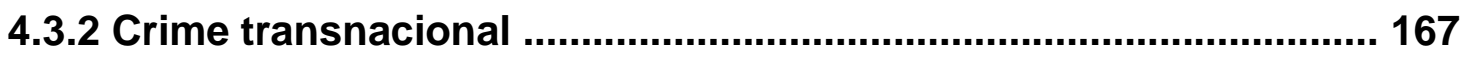

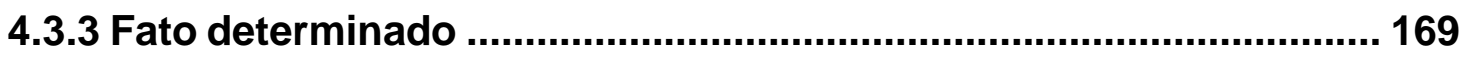

4.3.4 Ausência de hipótese impeditiva de cooperação ............................ 174

4.4 Dois ou mais países com jurisdição sobre o fato investigado ............. 177 


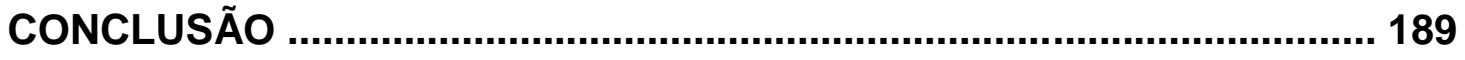

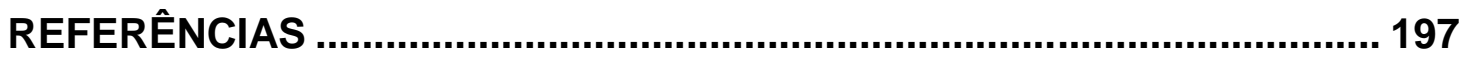

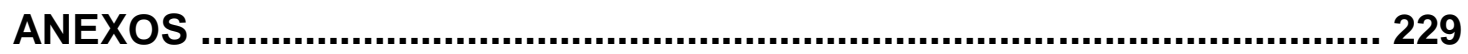




\section{INTRODUÇÃO}

No início da década de 1990, em interessante ilustração, o magistrado italiano Elvio Fassone já advertia que, se Arthur Conan Doyle fosse escrever seus romances policiais naquela época, seria necessário realizar uma significativa revisão das técnicas empregadas pelo célebre personagem Sherlock Holmes, uma vez que restos consumidos de cigarros, resíduos de terra nos sapatos, exame nas rodas dos carros, sinais de tinta nos dedos, ou seja, os "indícios clássicos" haviam desaparecido das cenas dos crimes, ao menos em relação aos ilícitos praticados, pela criminalidade organizada.

Com efeito, os desafios no enfrentamento dos delitos transnacionais, especialmente a inadequação dos tradicionais meios de obtenção de prova para a apuração daquelas espécies que extrapolem as fronteiras de um único Estado, e frequentemente cometidas por estruturas criminosas complexas, são temas comuns na doutrina nacional e na estrangeira.

Essa prática recorrente é consequência da abertura progressiva dos mercados e dos inúmeros avanços tecnológicos intensificados da segunda metade do século passado em diante, que facilitaram sobremaneira a circulação de bens, pessoas, serviços, capitais e informações, em uma escala mundial. Porém, a despeito dos inúmeros impactos positivos na sociedade, a globalização também propiciou incremento significativo na dispersão espacial da criminalidade.

A partir desse momento acentuou-se a dimensão transnacional das atividades criminosas, de modo que a abertura das fronteiras e dos mercados, assim como o desenvolvimento de novas tecnologias passaram a ser explorados tanto para a expansão das atividades delitivas quanto para assegurar a impunidade dos seus atos e dos respectivos proveitos ilícitos.

$E$, nesse contexto, evidenciou-se a inadequação do enfrentamento e investigação dos crimes com reflexos transnacionais e/ou cometidos por grupos organizados, com os mesmos instrumentos utilizados em relação à criminalidade 
comum. Até mesmo no que toca à cooperação jurídica internacional evidenciou-se a necessidade de aprimoramento dos mecanismos tradicionalmente empregados.

Assim, paulatinamente, desenvolveram-se novas técnicas de investigação ( $v$.g., entregas vigiadas, interceptações telefônicas e investigações encobertas), bem como novos mecanismos de auxílio mútuo internacional (v.g., videoconferência transnacional e Equipes Conjuntas de Investigação), com a finalidade de obter maior eficiência na atuação do Estado em face das atividades criminosas.

As Equipes Conjuntas de Investigação (ECls), cujo conceito será desenvolvido no presente trabalho, em apertada síntese, pode ser definida como os grupos formados por agentes designados por dois ou mais Estados, para a realização de uma investigação criminal determinada, de maneira unida e coordenada, e em um prazo certo. Trata-se de um peculiar e inovador instrumento de cooperação jurídica internacional pela via direta, que permite, sob certas condições, atuações transnacionais de seus membros e trâmite direto de informações e documentos no interesse da investigação.

Embora previstas em um documento da Organização das Nações Unidas (ONU) há quase trinta anos (Convenção de Viena de 1988), apenas a partir dos anos 2000, possivelmente impulsionados pelas disposições da Convenção Europeia de Auxílio Mútuo em Matéria Penal (União Europeia) e da Convenção de Palermo (ONU), é possível identificar as primeiras abordagens das ECls, especialmente na Europa. Na doutrina brasileira, salvo algumas poucas e tangenciais abordagens, não se tem notícia, por um lado, de nenhum estudo dedicado exclusivamente às ECls.

Por outro lado, a despeito do aparente desinteresse da doutrina pátria em relação às ECls, estão em vigor no Brasil, há um tempo bastante considerável, três convenções internacionais contemplando a possibilidade de formação desses grupos. Além disso, o tema vem sendo debatido em inúmeros foros internacionais no continente americano, sendo certo que o Brasil firmou no ano de 2010 o acordo do Mercosul que regulamenta a matéria. Entretanto, conforme demonstrado no Capítulo 3, durante abordagem do Acordo-Quadro de Cooperação entre os 
Estados-Partes do Mercosul e Estados Associados para a Criação de Equipes Conjuntas de Investigação, este ainda não entrou em vigor e, apesar de firmado, ainda não foi ratificado pelo Brasil.

É digno de registro, também, que no ano de 2014 os Procuradoresgerais do Brasil e da Argentina assinaram um acordo de cooperação internacional para a formação de uma Equipe Conjunta de Investigação - Justiça de Transição (ECI-JT), uma iniciativa pioneira e até o momento única de implementação efetiva do instituto no País. Esse acordo tem como propósito apurar os crimes cometidos pelas ditaduras militares de ambos os países, especialmente no âmbito da chamada Operação Condor, a colaboração entre os regimes ditatoriais do Cone Sul para prática de crimes contra a humanidade.

Outrossim, tem-se que em outubro de 2016 foi sancionada a primeira legislação nacional admitindo a formação de ECls (Lei 13.344/16), o que demonstra a relevância e a atualidade do tema. Ainda no final desse mesmo ano, o Conselho de Segurança da ONU exortou aos países à utilização de mecanismos de investigação conjunta no enfrentamento do terrorismo, mediante a Resolução no 2.322/2016.

Nesse contexto, o presente trabalho visa analisar as ECls e os seus requisitos de formação, ou seja, aqueles elementos considerados indispensáveis para a constituição válida de uma ECl. Para tanto, utiliza-se de fontes bibliográficas que examinam a doutrina, a legislação e a jurisprudência - nacionais e estrangeiras -, bem como documentos oficiais decorrentes de tratados e convenções, conjunto de material disponível em livros, periódicos e na internet.

Este estudo tem como ponto de partida a análise das inter-relações envolvendo globalização, crime transnacional e cooperação jurídica internacional. Nesse primeiro capítulo, abordam-se alguns conceitos fundamentais, bem como se apresenta a premissa na qual será pautada a abordagem das ECls no presente trabalho, qual seja, a indissociabilidade existente entre eficiência e garantismo na persecução penal. 
Desde logo, importa registrar que toda a análise das ECls é conduzida na perspectiva de que os instrumentos utilizados na investigação criminal, assim como aqueles empregados na cooperação jurídica internacional em matéria penal, devem proporcionar de modo simultâneo uma persecução criminal eficiente e o respeito a todas as garantias do cidadão investigado. Essa é a premissa que permeia todas as questões abordadas nesta dissertação, assim como suas respectivas conclusões.

O segundo capítulo se inicia com o desenvolvimento histórico das ECls, mediante abordagem que vai desde as primeiras experiências de colaboração direta entre forças policiais de países diversos até as primeiras normatizações das ECls. Na sequência, apresentam-se o conceito e a natureza jurídica, oportunidade em que alguns institutos homônimos e assemelhados serão distinguidos do objeto de estudo deste trabalho.

Reserva-se ao terceiro capítulo a elaboração de um amplo panorama das previsões normativas das ECls, englobando os instrumentos internacionais e aqueles estabelecidos apenas regionalmente tanto na Europa quanto na América. Nessa parte são apenas enunciadas as previsões da legislação internas de diversos países e, encerrada a abordagem, faz-se a análise da base normativa das ECls no Brasil.

Por fim, o quarto capítulo é dedicado ao estudo dos requisitos de formação das ECls à luz da eficiência e do garantismo. Com esse viés, procede-se a uma apreciação detalhada dos diversos elementos reputados imprescindíveis à constituição válida de uma $\mathrm{ECI}$, assunto objeto do capítulo conclusivo desta dissertação.

No item Conclusão, as ideias defendidas ao longo do estudo são retomadas para reflexão mais detida.

Ao final, apresentam-se anexos contendo documentos oficiais cuja facilidade de acesso torna-se cada vez mais rara, o que justifica sua inserção neste o trabalho. 


\section{CONCLUSÃO}

O presente estudo teve por escopo analisar Equipes Conjuntas de Investigação (ECls) e seus requisitos de formação, ou seja, aqueles elementos considerados indispensáveis para a constituição válida de uma ECI. A propósito, tem-se a salientar:

1. O surgimento de novas tecnologias, especialmente nas áreas da comunicação e informação, e o aperfeiçoamento dos sistemas de transporte foram fatores determinantes no processo de integração de mercados e de intensificação da circulação de bens, pessoas, serviços e bens em uma escala global.

2. A expansão internacional das atividades lícitas se fez acompanhar da dispersão geográfica do crime, circunstâncias que propiciaram o surgimento de novas modalidades criminosas e favoreceram a proliferação de múltiplas formas de delitos.

3. Os crimes transnacionais são os ilícitos com repercussão material e/ou jurídica além das fronteiras de um único Estado, decorrentes de uma das seguintes hipóteses: (i) prática de atos de execução no território de dois ou mais Estados; (ii) prática de atos de execução no território de um único Estado, mas que a preparação, o planejamento, a direção e/ou o controle da execução se deem em outro(s) Estado(s); ou (iii) prática de atos de execução no território de um único Estado, com ocorrência (ou projeção) de efeitos em outro(s) Estado(s).

4. A cooperação jurídica internacional em matéria penal é o conjunto de medidas adotadas no território de um país com a finalidade de permitir a investigação, o julgamento ou a execução de uma pena, no interesse da jurisdição penal de um Estado estrangeiro ou de uma organização de caráter supranacional.

5. Em um contexto em que os agentes criminosos e as respectivas fontes de provas estejam dispersas ao longo do território de vários Estados, a cooperação jurídica 
internacional é o único recurso capaz de viabilizar o exercício de sua persecução penal.

6. Para evitar que a facilitada transposição das fronteiras nacionais não representasse um obstáculo insuperável à ação do Estado diante dos crimes transnacionais, desenvolveram-se novas técnicas de investigação e novos mecanismos de auxílio mútuo entre os países (v.g., entregas vigiadas, interceptações telefônicas e investigações encobertas).

7. Estabelecida a premissa segundo a qual a finalidade do processo penal é a obtenção de um resultado justo, não existe antagonismo entre as noções de eficiência e garantismo, razão pela qual os instrumentos processuais devem proporcionar, simultaneamente, uma persecução criminal eficiente e o respeito às garantias do devido processo legal.

8. Atualmente, já está superada a percepção de que a cooperação jurídica internacional é desenvolvida na perspectiva exclusiva das relações internacionais e da repressão ao crime, reconhecendo-se o indivíduo requerido como titular de direitos e garantias estabelecidas na ordem interna e internacional.

9. A análise das Equipes Conjuntas de Investigação (ECls) em uma perspectiva histórica permite identificar o transcurso de um longo caminho, iniciado com atuações conjuntas transnacionais desenvolvidas em bases informais, até sua efetiva incorporação em instrumentos normativos interacionais.

10. Investigações conjuntas é um conceito amplo e variado, que comporta mais de um significado.

11. As investigações conjuntas, referidas nas Convenções de Palermo de 2000 (artigo 19) e Mérida de 2003 (artigo 39), não se distinguem das equipes conjuntas contempladas na Convenção de Viena de 1988 (artigo 9.1.c).

12. É possível identificar dois modelos de investigações conjuntas: o primeiro deles desenvolvido por intermédio de investigações paralelas - também referidas 
como investigações coordenadas ou investigações espelho -; e o outro, instrumentalizado pelas ECls.

13. Nas investigações paralelas - ou investigações espelho -, dois ou mais países, de maneira coordenada e simultânea, empreendem investigações sobre o mesmo fato criminoso, limitando-se as atuações aos seus respectivos domínios territoriais. Assim, tratando-se de investigações paralelas, quando necessária a prática de atos além das fronteiras dos Estados, é imprescindível a utilização das vias tradicionais de assistência jurídica, isto é, cartas rogatórias ou auxílio direto.

14. Nas ECls, representantes de dois ou mais países atuam de forma unida em uma mesma investigação criminal, com base em um acordo formal, por prazo certo e com um objeto de investigação determinado, admitindo-se a possibilidade de atuação transnacional e contatos diretos entre os agentes.

15. As ECls se distinguem das investigações paralelas pelas seguintes características: (i) possibilidade de alguma atuação extraterritorial dos agentes; (ii) contatos diretos entre os membros, com a consequente dispensa de utilização dos canais ordinários de cooperação jurídica internacional; (iii) existência de um acordo formal entre os países, definindo o prazo de funcionamento e o objeto a ser apurado.

16. As $\mathrm{ECl}$ são definidas como o grupo integrado por agentes de dois ou mais países, formado com base em um acordo específico para o desenvolvimento, coordenado e em um prazo certo, de uma investigação relativa a um crime transnacional, de modo a possibilitar sob certas condições, a atuação extraterritorial de seus membros e estabelecer uma via de contato direto entre seus participantes.

17. A expressão Equipes Conjuntas de Investigação pode ser utilizada, tanto para se referir ao grupo que realiza a investigação quanto para designar o próprio instrumento de cooperação jurídica internacional.

18. A expressão inglesa Joint Investigation Teams também denomina outros grupos de ação integrada que não se compatibilizam com o conceito de ECls apresentado no presente trabalho. 
19. As ECls são um instrumento inovador de cooperação jurídica internacional, cujo pedido é a realização de uma investigação conjunta, que tramita pela via do contato direto.

20. As ECls são um instrumento de cooperação jurídica internacional com características únicas, quais sejam, (i) natureza convencional; (ii) caráter recíproco; (iii) temporariedade; e (iv) especialidade.

21. O peculiar e inovador modelo de funcionamento das ECls proporciona maior eficiência na investigação de crimes transnacionais, sendo certo que essa percepção impulsionou a disseminação do instrumento, sobretudo no continente europeu.

22. As fontes normativas que admitem a formação das ECls derivam de instrumentos de natureza internacionais (bi ou multilaterais) e nacionais.

23. A Convenção contra o Tráfico llícito de Entorpecentes e Substâncias Psicotrópicas (Convenção de Viena de 1988) foi o primeiro instrumento adotado pela ONU contendo previsão específica acerca das ECls (artigo 9.1.c), naquele documento referidas como equipes conjuntas (em inglês, joint groups).

24. A Convenção das Nações Unidas contra o Crime Organizado Transnacional (Convenção de Palermo de 2000 - artigo 19) e a Convenção das Nações Unidas contra a Corrupção (Convenção de Mérida de 2003 - artigo 39) também contêm dispositivos atinentes às $\mathrm{ECls}$, nesses documentos referidas como investigações conjuntas (joint investigations).

25. As primeiras disposições convencionais regionais europeias a preverem a formação de ECls foram o Tratado de Amsterdã de 1997 e a Convenção de Nápoles II, também desse ano.

26. A Convenção de Auxílio Mútuo da União Europeia de 2000 representa um instrumento normativo fundamental para as ECls, na medida em que o detalhamento de seu modelo de funcionamento propiciou a deflagração de inúmeras iniciativas na Europa, contribuindo decisivamente para a difusão do instituto em escala mundial. 
27. No continente americano, inobstante o pioneirismo do Código de Procedimiento Penal da Bolívia de 1999, que previu e regulamentou as ECls antes mesmo da Convenção de Auxílio Mútuo da União Europeia de 2000, esse instrumento de cooperação jurídica internacional permanece até a presente data sem uma normatização regional em vigor.

28. Em 2010, no âmbito do Mercosul, foi firmado o Acordo-Quadro de Cooperação entre os Estados-Partes do Mercosul e Estados Associados para a Criação de Equipes Conjuntas de Investigação, mas, apesar de firmado por Argentina, Brasil, Paraguai, Uruguai, Bolívia, Equador e Colômbia, ainda não obteve o número mínimo de ratificações para início de sua vigência

29. Em 2013, o Convenio Iberoamericano de Equipos Conjuntos de Investigación foi aprovado e subscrito por Argentina, Costa Rica, Equador, El Salvador, Nicarágua, Panamá, Portugal e República Dominicana, mas até o momento também não entrou em vigor.

30. Diversos países, especialmente no continente europeu, já procederam à incorporação das ECls aos seus ordenamentos jurídicos nacionais.

31. O primeiro requisito de formação de uma ECI é a autorização legal, ou seja, a existência de um fundamento normativo que expressamente admita a utilização desse instrumento

32. No Brasil, a formação das ECls é admitida com base nas Convenções da ONU de Viena de 1988, Palermo de 2000 e Mérida de 2003, bem como na Lei no $13.344 / 2016$.

33. A ausência de previsão legal do procedimento de formação e funcionamento, no plano normativo internacional e interno, não constitui óbice intransponível ao estabelecimento e ao funcionamento das ECls no Brasil, desde que respeitados todos os direitos e garantias assegurados na Constituição da República.

34. Em havendo consentimento entre todos os Estados, ou seja, em caso de manifestação de vontades convergente e concertada, dois ou mais países 
poderão formar ECls para o desenvolvimento unido e coordenado de determinada investigação criminal.

35. Os Estados podem conformar as ECls casuisticamente às exigências do caso concreto, às especificidades dos ordenamentos internos dos países envolvidos e, até mesmo, ao grau de confiança mútua entre os envolvidos

36. No que tange ao objeto da investigação, as ECls são constituídas para o desenvolvimento de investigação de um crime transnacional determinado.

37. Em se tratando de instrumentos de cooperação jurídica internacional, apenas nas hipóteses de investigação de fatos ilícitos cujos atos de preparação, execução e/ou consumação extrapolem as fronteiras de um único Estado será possível formar uma ECl.

38. As ECls são formadas para o desenvolvimento de investigação de um fato determinado, ou seja, o objeto sobre o qual recairá a investigação deve ser definido no momento de sua instituição.

39. Em virtude do modelo diferenciado de funcionamento das ECls, a formação desse instrumento de cooperação jurídica internacional deve ser concretamente fundamentada, demonstrando-se a absoluta necessidade de sua formação na hipótese, ou seja, as ECls são instrumentos de utilização excepcional, reservadas àquelas hipóteses em que as circunstâncias específicas do caso revelem a inadequação dos demais mecanismos de auxílio mútuo.

40. A ausência de hipótese impeditiva de cooperação jurídica internacional apresenta-se como verdadeiro requisito negativo à formação das ECls, devendo ser casuisticamente analisada a legislação de regência - tratado bilateral ou convenção em que se baseia o pedido - e aferida a possibilidade jurídica da formação do grupo.

41. O modelo diferenciado de cooperação jurídica internacional possibilitado pelas ECls - em especial, as atuações extraterritoriais e os contatos direitos - é circunstância que impõe a utilização excepcional do instrumento em comento. Desse modo, para a formação de uma ECl é necessário que haja uma vinculação 
entre o objeto da investigação e os Estados interessados em sua constituição, isto é, os países devem, ao menos em tese, possuir jurisdição sobre os fatos criminosos que serão objeto da apuração.

42. A constituição de uma $\mathrm{ECl}$ requer, também, que os Estados interessados elaborem e subscrevam um documento - frequentemente referido como acordo de constituição - que formalize sua criação, permita identificar seu objeto e membros, assim como defina algumas diretrizes relativas ao seu funcionamento.

43. Na medida em que a determinação objetiva e a limitação temporal são características indissociáveis de uma $\mathrm{ECl}$, é imprescindível que venham identificadas de modo expresso em seu documento de formação.

44. Como manifestação da soberania estatal, os próprios países deverão estabelecer no acordo os exatos limites da atuação extraterritorial dos agentes - nacionais e estrangeiros -, conforme permitido em sua legislação interna.

45. O acordo de constituição deverá contemplar a forma de trânsito das informações e documentos entre os membros do grupo, dispondo necessariamente sobre seu controle e registro.

Diante do que foi exposto, pode-se verificar que as ECls são um instrumento de cooperação jurídica internacional de caráter peculiar inovador, ainda negligenciado tanto pela doutrina nacional quanto pelos operadores do direito. 


\section{REFERÊNCIAS}

ABADE, Denise Neves. Direitos fundamentais na cooperação jurídica internacional: extradição, assistência jurídica, execução de sentença estrangeira e transferência de presos. São Paulo: Saraiva, 2013.

ABBELL, Michael. Obtaining evidence abroad in criminal cases. Ardsley, N.Y.: Transnational Publishers, 2010.

ACCIOLY, Hildebrando; SILVA, Geraldo Eulálio da; CASELLA, Paulo Borba. Manual de direito internacional público. 19. ed. São Paulo: Saraiva, 2012.

ALBANESE, Jay; DAS, Dilip; VERMA, Arvind (Ed.). Organized crime: world perspectives. Mishawaka: Prentice Hall, 2003.

ALEGRE, Clara Penín. Cooperación jurídica internacional. In: SERRANO, Nicolás González-Cuéllar; HERMIDA, Ágata M. Sanz; PRADILLO; Juan Carlos Ortiz. Problemas actuales de la justicia penal: secreto profesional, cooperación jurídica internacional, víctimas de delitos. Madrid: Colex, 2013.

ALFARO, Ricardo Joaquín. The rights and duties of states. La Haye: Académie de Droit International de La Haye, 1959. v. 97.

ALSTON, Philip; GOODMAN, Ryan. International human rights. Oxford: Oxford University Press, 2012.

ALVES COSTA, Jorge A. Cooperación judicial entre Portugal y España. Los equipos conjuntos de investigación. In: ARANGÜENA FANEGO, Coral (Coord.). Cooperación judicial civil y penal en el nuevo escenario de Lisboa. Granada: Comares, 2011.

AMBOS, Kai. La parte general del derecho penal internacional: bases para una elaboración dogmática. Traducción de Ezequiel Malarino. Berlin: Duncker und Humblot, Konrad-Adenauer Stiftung; Montevideo: Temis, 2005.

AMICIS, Gaetano de. Cooperazione giudiziaria e corruzione internazionale: verso un sistema integrato di forme e strumenti di collaborazione tra le autorità giudiziarie. Milano: Giuffrè, 2007.

ANAND, Ram Prakash. Sovereign equality of states in international law. La Haye: Académie de Droit International de La Haye, 1986. v. 197. (Recueil des cours).

ANDERSON, Malcolm et al. Policing the European Union. Oxford: Oxford University Press, 1996.

ANDREAS, Peter. Transnational crime and economic globalization. In: BERDAL, Mats R. Transnational organized crime and international security: business as usual? Lynne Rienner Publishers, 2002. 
ANDREAS, Peter; NADELMANN, Ethan. Policing the globe: criminalization and crime control in international relations. New York: Oxford University Press, 2006.

ANODINA, Elena. Cooperazione-integrazione penale nell'Unione europea. Cassazione Penale, v. 41, n. 10, p. 2898-2916, 2001.

ANZILOTTI, Dionisio. // diritto internazionale nei giudizi interni. Bologna: Ditta N. Zanichelli, 1905.

ARANGÜENA FANEGO, Coral (Coord.). Cooperación judicial civil y penal en el nuevo escenario de Lisboa. Granada: Comares, 2011.

ARAS, Vladimir. Direito probatório e cooperação jurídica internacional. In: SALGADO, Daniel; QUEIROZ, Ronaldo. A prova no enfrentamento à macrocriminalidade. Salvador: Juspodivm, 2015.

O papel da autoridade central nos acordos de cooperação penal internacional. In: BALTAZAR JÚNIOR, José Paulo; LIMA, Luciano Flores de (Orgs.). Cooperação jurídica internacional em matéria penal. Porto Alegre: Verbo Jurídico, 2010.

ARAÚJO, Luiz Alberto; PRADO, Luiz Regis. Alguns aspectos das limitações ao direito de extraditar. Revista de Informação Legislativa, ano 19, n. 76, p. 65-86, out./dez. 1982.

ARMONE, Giovanni M. et al. Diritto penale europeo e ordinamento italiano: le decisioni quadro dell'Unione europea: dal mandato d'arresto alla lotta al terrorismo. Milano: Giuffrè, 2006.

ASSIS MOURA, Maria Thereza Rocha de. As reformas no processo penal: as novas leis de 2008 e os projetos de reforma. São Paulo: Revista dos Tribunais, 2008.

AZEVEDO, Antônio Junqueira de. Negócio jurídico: existência, validade e eficácia. 4. ed. São Paulo: Saraiva, 2013.

BADARÓ, Gustavo Henrique; BOTTINI, Pierpaolo Cruz. Lavagem de dinheiro: aspectos penais e processuais penais: comentários à Lei 9.613/1998, com as alterações da Lei 12.683/2012. São Paulo: Revista dos Tribunais, 2012.

BADARÓ, Gustavo. Manual dos recursos penais. São Paulo: Revista dos Tribunais, 2016.

Manual de processo penal. 3. ed. São Paulo: Revista dos Tribunais, 2015.

Processo penal. 3. ed. São Paulo: Revista dos Tribunais, 2015.

BADARÓ, José Raymundo Ramagem. Comentários ao código penal militar de 1969. São Paulo: Juriscrédi, 1972. 
BAKKER, Edwin; POWDERLY, Joseph. Dealing with transnational terrorism, the concept and practice of joint investigation teams. Security and Human Rights, v. 22, n. 1, p. 19-28, 2011.

BALDUCCI, Paola. Profili sostanziali e processuali del traffico di stupefacenti. Le azioni simulate. Testo dell'intervento, Consiglio Superiore della Magistratura, Incontro di studio, Roma, 14-16 mar. 2005.

BALTAZAR JUNIOR, José Paulo. Crime organizado e proibição da insuficiência. Porto Alegre: Livraria do Advogado, 2010.

; LIMA, Luciano Flores de (Orgs.). Cooperação jurídica internacional em matéria penal. Porto Alegre: Verbo Jurídico, 2010.

BANTEKAS, Ilias; NASH, Susan. International criminal law. 3rd ed. London; New York: Routledge-Cavendish, 2007.

BAPTISTA, Luiz Olavo; FONSECA, José Roberto Franco da (Coord.). O direito internacional no terceiro milênio: estudos em homenagem ao Professor Vicente Marotta Rangel. São Paulo: LTr, 1998.

BARBOSA MOREIRA, José Carlos. Comentários ao código de processo civil. 17. ed. Rio de Janeiro: Forense, 2013.

Questões velhas e novas em matéria de classificação das sentenças. In: Temas de direito processual civil: oitava série. São Paulo: Saraiva, 2004.

Temas de direito processual civil: oitava série. São Paulo: Saraiva, 2004.

BARBOSA, Ruy. Deuxième conférence de la paix. La Haye: W. P. van Stockum et fils, 1907.

BASSIOUNI, Cherif; MILITELLO, Vincenzo; SATZGER, Helmut (Ed.). European cooperation in penal matters: issues and perspectives: lectures and materials of the specialization courses in European criminal law. Padova: Cedam, 2008.

BASSIOUNI, M. Cherif (Ed.). International Criminal Law: multilateral and bilateral enforcement mechanisms. Leiden: Brill Academic Publishers, 2008. v. 2.

BEARE, Margaret. E. Critical reflections on transnational organized crime, money laundering and corruption. Toronto: University of Toronto Press, 2003.

BECHARA, Fábio Ramazzini. Cooperação jurídica internacional em matéria penal: eficácia da prova produzida no exterior. São Paulo: Saraiva, 2011.

BECK, Francis Rafael. Perspectivas de controle ao crime organizado e crítica à flexibilização das garantias. São Paulo: Ibccrim, 2004.

BECK, Ulrich. O que é globalização? Equívocos do globalismo: respostas à globalização. Tradução de André Carone. São Paulo: Paz e Terra, 1999. 
BECK, Ulrich. Sociedade de risco: rumo a uma outra modernidade. São Paulo: Editora 34, 2010.

BENOÎT-ROHMER, Florence; KLEBES, Heinrich. Le droit du Conseil de l'Europe: vers un espace juridique européen. Strasbourg: Council of Europe, 2005.

BERDAL, Mats R.; SERRANO, Mónica. Transnational organized crime and international security: business as usual? Boulder, Co.: Lynne Rienner Publishers, 2002.

(Comp.). Crimen transnacional organizado y seguridad internacional: cambio y continuidad. Ciudad del México: Fondo de Cultura Económica, 2005.

BLOCK, Ludo. EU joint investigation teams: political ambitions and police practices. In: HUFNAGEL, Saskia; HARFIELD, Clive; BRONITT, Simon (Ed.). Cross-border law enforcement: regional law enforcement cooperation - European, Australian and Asia-Pacific perspectives. London: Taylor \& Francis, 2012.

. Joint investigation teams: the panacea for fighting Organised Crime? ECPR $\overline{\text { Annual }}$ Conference, August 2011.

BOISTER, Neil. The UN Convention against Transnational Organized Crime (2000). In: HAUCK, Pierre; PETERKE, Sven (Ed.). International Law and Transnational Organised Crime. Oxford; New York: Oxford University Press, 2016.

Press, 2012.

An introduction to transnational criminal law. Oxford: Oxford University

. Transnational criminal law? European Journal of International Law, v. 14, n. 5, p. 953-976, Nov. 2003.

; CURRIE, Robert J. (Ed.). Routledge Handbook of Transnational Criminal Law. London: Routledge, 2014.

BOSSARD, André. Transnational crime and criminal law. Chicago: University of Illinois at Chicago, 1990.

BROWNLIE, lan. Principles of public international law. 7th ed. New York: Oxford University Press, 2008.

BRUINSMA, G. (Ed.). Histories of transnational crime. New York: Springer, 2015.

BRUINSMA, Gerben. Criminology and transnational crime. In: BRUINSMA, Gerben. (Ed.). Histories of transnational crime. New York: Springer, 2015

BULNES, Mar Jimeno. La cooperación judicial civil y penal en el ámbito de la Unión Europea: instrumentos procesales. Barcelona: Bosch, 2007.

BUNTE, Marco; UFEN, Andreas (Ed.). Democratization in Post-Suharto Indonesia. London: Routledge, 2008. 
CABIALE, Andrea. Verso una prospettiva di disciplina delle squadre investigative comuni? La Legislazione Penale, n. XXXIV, v. 1-2, p. 121-127, 2014

CABRAL, Antonio do Passo. Convenções processuais. Salvador: Juspodivm, 2016.

CALABRICH, Bruno. Investigação criminal pelo Ministério Público. São Paulo: Revista dos Tribunais, 2006.

CALDAS AULETE, Francisco Julio. Dicionário contemporâneo da língua portuguesa. 3. ed. Lisboa: Parceria António Maria Pereira, 1948. v. 1.

CALLEGARI, André Luis; WEBER, Ariel Barazzeti. Lavagem de dinheiro. São Paulo: Atlas, 2014.

(Org.). Crime organizado: tipicidade, política criminal e investigação e processo: Brasil, Espanha e Colômbia. Porto Alegre: Livraria do Advogado, 2008.

CALVANESE, Ersília. Adesione al trattato di Prüm e cooperazione transfrontaliera per il contrasto alla criminalità. In: SCARCELLA, Alessio (Ed.). Prelievo del DNA e banca dati nazionale: il proceso penale tra accertamento del fatto e cooperazione internazionale. Padova: Cedam, 2009.

2001.

. Indagini congiunte: un'occasione sprecata. Guida al Diritto, n. 42, p. 35-45,

CALVO, Carlos. Dictionnaire manuel de diplomatie et de droit international public et privé. New Jersey: The Lawbook Exchange, 2009.

CAMPBELL, Liz. Organised crime and the law: a comparative analysis. London: Bloomsbury Publishing, 2013.

CANÇADO TRINDADE, Antonio Augusto. Memorial em prol de uma nova mentalidade quanto à proteção dos direitos humanos nos planos internacional $\mathrm{e}$ nacional. Revista da Faculdade de Direito da UFMG, v. 36, n. 36, p. 27-76, 1999.

A proteção internacional dos direitos humanos: fundamentos jurídicos e instrumentos básicos. São Paulo: Saraiva, 1991.

CARMONA RUANO, M.; GONZÁLEZ VEGA, I. U.; MORENO CATENA, V. (Dir.). Cooperación judicial penal en Europa. Madrid: Dykinson, 2013.

CARNELUTTI, Francesco. Sistemas de direito processual civil. 2. ed. São Paulo: Lemos \& Cruz, 2004. v. III.

CARTA DAS NAÇÕES UNIDAS (Decreto no 19.841/1945). Disponível em: <https://www.unicef.org/brazil/pt/resources_10134.htm>. Acesso em: 3 jan. 2017.

CARVALHO RAMOS, André de. Direito internacional privado e seus aspectos processuais: a cooperação jurídica internacional. In: CARVALHO RAMOS, André de; MENEZES, Wagner. Direito internacional privado e a nova cooperação jurídica internacional. Belo Horizonte: Arrases, 2014. 
CARVALHO RAMOS, André de. Pluralidade das ordens jurídicas: a relação do direito brasileiro com o direito internacional. Curitiba: Juruá, 2012.

; MENEZES, Wagner. Direito internacional privado e a nova cooperação jurídica internacional. Belo Horizonte: Arrases, 2014.

CARVALHO, Paulo de Barros. Direito tributário: linguagem e método. 5. ed. São Paulo: Noeses, 2013.

CASELLA, Paulo Borba. Direito internacional no tempo moderno de Suarez a Grócio. São Paulo: Atlas, 2014.

Atlas, 2012.

Direito Internacional no tempo medieval e moderno até Vitoria. São Paulo:

; SANCHEZ, Rodrigo Elian. Cooperação judiciária internacional. Rio de Janeiro: Renovar, 2002.

CASSESE, Antonio et al. International criminal law: cases and commentary. Oxford: Oxford University Press, 2011.

CERVINI, Raúl. Conceito e alcance da cooperação penal internacional lato senso. In: CERVINI, Raúl; TAVARES, Juarez. Princípios de cooperação judicial penal internacional no protocolo do Mercosul. São Paulo: Revista dos Tribunais, 2000.

; TAVARES, Juarez. Princípios de cooperação judicial penal internacional no protocolo do Mercosul. São Paulo: Revista dos Tribunais, 2000.

CHOCLÁN MONTALVO, José Antonio. Delincuencia transfronteriza y equipos conjuntos de investigación. In: GALGO PECO, Ángel (Org.). Derecho penal supranacional y cooperación jurídica internacional. Colección Cuadernos de Derecho Judicial, Madrid: Consejo General del Poder Judicial, año 2003, n. XIII, p. 159-188, 2004.

Delincuencia transfronteiriza y equipos conjuntos de investigación. In: GALCO PECO, Ángel (Org.). Colección Cuadernos de Derecho Judicial XIII-2003. Madrid: Consejo General del Poder Judicial, 2004.

CIAMPI, Annalisa. L'assunzione di prove all'estero in materia penale. Padova: Cedam, 2003.

CINTRA, Antonio Carlos Araújo GRINOVER, Ada Pellegrini; DINAMARCO, Cândido Rangel. Teoria geral do processo. 27. ed. São Paulo: Malheiros, 2011.

COLOMBIA (Gobierno). Constitución Política de Colombia de 20 de julio de 1991. Disponível em: <http://www.constitucioncolombia.com/indice.php>. Acesso em: 12 out. 2016.

CUNHA, Rogério Sanches; TAQUES, Pedro; GOMES, Luiz Flávio (Coord.). Limites constitucionais da investigação. São Paulo: Revista dos Tribunais, 2009. 
D'AMATO, Antonio La cooperazione internazionale nell'esercizio della funzione giurisdizionale: dalle rogatorie alle squadre investigative comuni in attuazione dei principi del 'terzo pilastro' del trattato sull'Unione Europea. In: PATALANO, Vicenzo. Nuove strategie per la lotta al crimine organizzato transnazionale. Torino: Giappichelli, 2003.

DALLARI, Pedro B. A. Constituição e tratados internacionais. São Paulo: Saraiva, 2003.

DAVID, Eric. La coopération judiciaire et pénale en matière d'enquête et d'instruction. In: (Org.). Eléments de droit pénal international et européen. Bruxelles: Bruylant, 2009.

(Org.). Eléments de droit pénal international et européen. Bruxelles: Bruylant, 2009.

DE ARAÚJJ, Edmir Netto. Do negócio jurídico administrativo. São Paulo: Revista dos Tribunais, 1992.

DE ARAUJO, Nadia. Direito internacional privado: teoria e prática brasileira. 6. ed. EBook, 2016.

DE BUCK, Bart. Joint investigation teams: the participation of Europol officials. ERA Forum, n. 8, p. 253-264, 2007.

DE BUSSER, Els. Judicial cooperation in criminal matters-mutual legal assistance. In: RIJKEN, Connie; VERMEULEN, Gert. Joint investigation teams in the European Union: from theory to practice. The Hague: T. M. C. Asser Press, 2006.

DE CARLI, Carla Veríssimo. Lavagem de dinheiro: prevenção e controle penal. Porto Alegre: Verbo Jurídico, 2012.

. O sistema internacional antilavagem de dinheiro. In: Lavagem de dinheiro: prevenção e controle penal. Porto Alegre: Verbo Jurídico, 2012.

Lavagem de dinheiro: ideologia da criminalização e análise do discurso. Porto Alegre: Verbo Jurídico, 2008.

DE FELIPE, Miguel Beltrán; MARTíN, Adán Nieto. Post 9/11 Trends in International Judicial Cooperation Human Rights as a Constraint on Extradition in Death Penalty Cases. Journal of International Criminal Justice, v. 10, n. 3, 2012.

DE KERCHOVE, Gilles. Vers un espace judiciaire pénal européen: towards a European judicial criminal area. Bruxelas: Éditions de l'Université de Bruxelles, 2000.

DE MOOR, Alexandra. Joint investigation teams: Belgium, the Netherlands, the United Kingdom Can (or Should) Europol Participate? Dissertation (Master) Universiteit Gent, 2006.

DE PLÁCIDO E SILVA, Oscar Joseph. Vocabulário jurídico - A-C. Rio de Janeiro: Forense, 1978. v. I. 
DE PLÁCIDO E SILVA, Oscar Joseph. Vocabulário jurídico - J-P. Rio de Janeiro: Forense, 1978. v. III.

. Vocabulário jurídico - Q-Z. Rio de Janeiro: Forense, 1978. v. IV.

DE SOUZA, Solange Mendes. Cooperação jurídica penal no Mercosul: novas possibilidades. Rio de Janeiro: Renovar, 2001.

DEFLEM, Mathieu. Wild beasts without nationality. Handbook of Transnational Crime and Justice: Special Offer Edition. London: Sage, 2005.

- Policing world society: historical foundations of international police cooperation. Oxford, New York: Oxford University Press, 2002.

International policing in Nineteenth-Century Europe: the Police Union of German States, 1851-1866. International Criminal Justice Review, n. 6, p. 36-57, 1996.

; MCDONOUGH, Shannon. International law enforcement organizations. In: KETHINENI, Sesha. Comparative and International Policing, Justice, and Transnational Crime. 2nd. ed. 2014.

DI NICOLA, Andrea et al. (Orgs.). Study on paving the way for future policy initiatives in the field of fight against organised crime: the effectiveness of specific criminal law measures targeting organised crime - final report. Luxembourg: European Commission, February 2015.

DIDIER JR., Fredie. Curso de direito processual civil. 17. ed. Salvador: Juspodivm, 2015.

DINAMARCO, Cândido Rangel. Instituições de direito processual civil. 6. ed. 2009. V. II-III.

DIOTALLEVI, Giovanni. La c.d. "concelebrazione" delle rogatorie e gli atti diretti di giurisdizione all'estero (Nota a Cass. sez. V pen. 14 ottobre 1996). Cassazione Penale, n. 3, p. 915-918, 1998.

EINSTEIN S. AMI, M. Organized crime: uncertainties and dilemmas. Chicago: University of Illinois at Chicago, 1999.

ESER, Albin; LAGODNY, Otto. Principles and procedures for a new transnational criminal law. Freiburg: Society for the Reform of Criminal Law and Max Planck Institute for Foreign and International Criminal Law, 1992.

FARO JUNIOR, Luiz P. F. de. Direito internacional público. Rio de Janeiro: Borsoi, 1965.

FELSEN, David; KALAITZIDIS, Akis. A historical overview of transnational crime. In: REICHEL, Philip. Handbook of transnational crime and justice. New York: Sage publications, 2005. 
FERNANDES, Antonio Scarance. Terrorismo - eficiência e garantismo. In:

ZILLI, Marcos Alexandre Coelho. Terrorismo e justiça penal: reflexões sobre a eficiência e o garantismo. São Paulo: Fórum, 2014.

O direito processual penal internacional. In: ; ZILLI, Marcos Alexandre Coelho (Orgs.). Direito processual penal internacional. São Paulo: Atlas, 2013. 2012.

. Processo penal constitucional. 7. ed. São Paulo: Revista dos Tribunais,

O equilíbrio na repressão ao crime organizado. In: ; ALMEIDA, José Raul Gavião de; MORAES, Maurício Zanóide de. Crime organizado: aspectos processuais. São Paulo: Revista dos Tribunais, 2009.

penal. In:

Reflexões sobre as noções de eficiência e de garantismo no processo penal: eficiência e garantismo. São Paulo: Revista dos Tribunais, 2008.

Prova e sucedâneos da prova no processo penal. Revista Brasileira de Ciências Criminais, v. 15, n. 66, p. 193-236, maio/jun. 2007.

Teoria geral do procedimento e o procedimento no processo penal. São Paulo: Revista dos Tribunais, 2005.

; ALMEIDA, José Raul Gavião de; MORAES, Maurício Zanóide de. Crime organizado: aspectos processuais. São Paulo: Revista dos Tribunais, 2009.

; MORAES, Maurício Zanóide de. Sigilo no processo penal: eficiência e garantismo. São Paulo: Revista dos Tribunais, 2008.

; ZILLI, Marcos Alexandre Coelho. Terrorismo e justiça penal: reflexões sobre a eficiência e o garantismo. São Paulo: Fórum, 2014.

2013. (Orgs.). Direito processual penal internacional. São Paulo: Atlas,

FERNANDES, Paulo Silva. Globalização, "sociedade de risco" e o futuro do direito penal: panorâmica de alguns problemas comuns. Lisboa: Almedina, 2001.

FERRAJOLI, Luigi. Direito e razão: teoria do garantismo penal. São Paulo: Revista dos Tribunais, 2006.

FERREIRA, Aurélio Buarque de Holanda. Dicionário Aurélio de língua portuguesa. 5. ed. São Paulo: Positivo, 2010.

FIGUEIREDO DIAS, Jorge de. Direito processual penal. Coimbra: Coimbra, 1974. v. 1.

FIJNAUT, Cyrille. Schengen Treaties and European Police Cooperation. The Eur. J. Crime Crim. L. \& Crim. Just., v. 1, p. 37-56, 1993. 
FIJNAUT, Cyrille. Transnational crime and the role of the United Nations in its containment through international cooperation: a challenge for the 21 st century. European Journal of Crime Criminal Law and Criminal Justice, v. 8, n. 2, p. 119128, 2000.

FILIPPI, Leonardo et al. (Eds.). La circolazione investigativa nello spazio giuridico europeo: strumenti, soggetti, risultati. Padova: Cedam, 2010.

FISCHER, Douglas. O que é garantismo penal (integral). In: CALABRICH, Bruno; FISHER, Douglas; PELELLA, Eduardo. Garantismo penal integral: questões penais e processuais, criminalidade moderna e a aplicação do modelo garantista no Brasil. 3. ed. Salvador: Juspodivm, 2015.

FLETCHER, Maria; GILMORE, William C. EU criminal law and justice. Cheltenham: Edward Elgar Publishing, 2010.

FRIEDRICHS, David O.; FRIEDRICHS, Jessica. The World Bank and crimes of globalization: a case study. Social Justice, v. 29, n. 1/2, p. 13-36, 2002.

FRIEDRICHS, Jörg. Fighting terrorism and drugs: Europe and international police cooperation. London: Routledge, 2007.

GALGO PECO, Ángel (Org.). Derecho penal supranacional y cooperación jurídica internacional. Colección Cuadernos de Derecho Judicial, Madrid: Consejo General del Poder Judicial, año 2003, n. XIII, p. 159-188, 2004.

GALLAGHER, Anne T.; DAVID, Fiona. The international law of migrant smuggling. New York: Cambridge University Press, 2014.

GARCÍA SÁNCHEZ, Beatriz. Medios legales en la persecución de la delincuencia organizada. Eficaces y legitimos. In: MORÁN BLANCO, Maria del Sagrario; ROPERO CARRASCO, Julia; GARCÍA SÁNCHEZ, Beatriz. Instrumentos internacionales en la lucha contra la delincuencia organizada. Madrid: Dykinson, 2011.

GARCíA, Enrique Vallines. Los equipos conjuntos de investigación penal en el marco de la cooperación policial y judicial entre los Estados de la Unión Europea. Barcelona: Editorial Colex, 2006.

GARDNER, Maggie. Channeling Unilateralism. Harvard International Law Journal, v. 56, n. 2, p. 297-351, 2015.

GAZZETTA UFFICIALE DELLA REPUBBLICA ITALIANA, n. 90, 6 mar 1976.

GERBER, David J. Beyond balancing: international law restraints on the reach of National Laws. Yale Journal of International Law, v. 10, p. 185-221, 1984.

GIDDENS, Anthony. As consequências da modernidade. São Paulo: Unesp, 1990. . Mundo em descontrole. São Paulo: Record, 2000. 
GIDDENS, Anthony. Sociologia. 4. ed. Lisboa: Fundação Calouste Gulbenkian, 2004.

GIDEL, Gilbert. La théorie des droits fondamentaux des états a quelques moments caractéristiques de son développement. La Haye: Académie de Droit International de La Haye, 1925. v. 10. (Recueil des cours).

GIOVANNI, Melillo. II tormentato cammino delle squadre investigative comuni fra obblighi internazionali e legislazione nazionale. Diritto Penale e Processo, n. 1, p. 121-126, 2008.

GOMES FILHO, Antonio Magalhães. Provas - Lei 11.690, de 09.06.2008. In: ASSIS MOURA, Maria Thereza Rocha de. As reformas no processo penal: as novas leis de 2008 e os projetos de reforma. São Paulo: Revista dos Tribunais, 2008.

Notas sobre a terminologia da prova: reflexos no processo penal brasileiro. In: YARSHELL, Flávio Luiz; ZANOIDE DE MORAES, Maurício (Org.). Estudos em homenagem à professora Ada Pellegrini Grinover. São Paulo: DPJ, 2005.

. Direito à prova no processo penal. São Paulo: Revista dos Tribunais, 1997.

GRECO FILHO, Vicente. Manual de processo penal. 10. ed. São Paulo: Saraiva, 2013.

A entrega vigiada e o tráfico de pessoas. In: MARZAGÃO JR., Laerte; GRECO, Alessandra Orcesi Pedro. Tráfico de pessoas. São Paulo: Quartier Latin, 2010.

GRINOVER, Ada Pellegrini. Ensaio sobre a processualidade: fundamentos para uma nova teoria geral do processo. Brasília: Gazeta Jurídica, 2016.

As garantias processuais na cooperação internacional em matéria penal. In: BAPTISTA, Luiz Olavo; FONSECA, José Roberto Franco da (Coord.). O direito internacional no terceiro milênio: estudos em homenagem ao Professor Vicente Marotta Rangel. São Paulo: LTr, 1998.

. Lineamentos gerais do novo processo penal na América Latina: Argentina, Brasil e Código modelo para Ibero-América. In: 2. ed. São Paulo: Forense, 1998. O processo em evolução.

. O processo em evolução. 2. ed. São Paulo: Forense, 1998.

. Processo penal transnacional: linhas evolutivas e garantias processuais. In:___ O processo em evolução. Rio de Janeiro: Forense, 1998.

. Processo penal transnacional: linhas evolutivas e garantias processuais. Revista Forense, Rio de Janeiro, v. 91, p. 3-37, 1995.

. O processo em sua unidade. São Paulo: Saraiva, 1978.

. Pressupostos processuais e processo penal. In: O processo em sua unidade. São Paulo: Saraiva, 1978. 
GRINOVER, Ada Pellegrini; GOMES FILHO, Antonio Magalhães; FERNANDES, Antonio Scarance. Recursos no processo penal. 7. ed. Saraiva: São Paulo, 2011.

et al. Proposta de código modelo de cooperação interjurisdicional para Ibero-América. Revista da Escola Nacional de Magistratura, v. 4, p. 98-112, 2008.

GROTIUS, Hugo. De jure belli ac Pacis Libri Tres. Trad. Franacis W. Kelsey. Washington: Carnegie Institution of Washington, 1913.

GUALTIERI, Claudia. Joint investigation teams. ERA Forum, v. 8, p. 233-238, 2007.

GULLY-HART, Paul. Cooperation between central authorities and police officials: the changing face of international legal assistance in criminal matters. Revue Internationale de Droit Pénal, v. 76, n. 1, p. 27-48, 2005.

HARFIELD, Clive Geoffrey. Process and practicalities: mutual legal assistance and the investigation of transnational crime within the EU from a UK perspective, 19902004. December 2004. 284 p. Doctorate (Thesis) - Faculty of Law, Arts and Social Sciences of the University of Southampton, May 2005.

. Process and practicalities: mutual legal assistance and the investigation of transnational crime within the EU from a UK perspective, 1990-2004. December 2004. 284 p. Doctorate (Thesis) - Faculty of Law, Arts and Social Sciences of the University of Southampton, May 2005.

HAUCK, Pierre; PETERKE, Sven (Ed.). International Law and Transnational Organised Crime. Oxford; New York: Oxford University Press, 2016.

HERZ, Annette. The role of Europol and Eurojust in joint investigation teams. In: RIJKEN, Connie; VERMEULEN, Gert. Joint investigation teams in the European Union: from theory to practice. The Hague: T. M. C. Asser Press, 2006.

HIRST, Paul; THOMPSON, Grahame. Globalização em questão. Petrópolis: Vozes, 1998.

HOMERO. Odisséia. Tradução e prefácio de Frederico Lourenço. 2. reimp. São Paulo: Penguin Classics Cia. das Letras, 2011.

HORVATITS, Lisa; DE BUCK, Bart. The Europol and Eurojust project on joint investigation teams. ERA Forum, n. 8, p. 239-243, Jun. 2007.

HOUAISS, Antônio; VILLAR, Mauro de Salles. Dicionário Houaiss de língua portuguesa. Rio de Janeiro: Objetiva, 2009.

HUFNAGEL, Saskia. Policing cooperation across borders: comparative perspectives on law enforcement within the EU and Australia. Routledge, 2016.

Strategies of police cooperation: comparing the Southern Chinese seaboard with the European Union. Crime, Law and Social Change, v. 61, n. 4, p. 377-399, May 2014. 
HUFNAGEL, Saskia. Transnational organized crime: police cooperation in China and the EU. Griffith Asia Quarterly, v. 2, n. 1, p. 75-92, 2014.

; HARFIELD, Clive; BRONITT, Simon (Ed.). Cross-border law enforcement: regional law enforcement cooperation - European, Australian and Asia-Pacific perspectives. London: Taylor \& Francis, 2012.

; MCCARTNEY, Carole. Police cooperation against transnational criminals. In: BOISTER, Neil; CURRIE, Robert J. (Ed.). Routledge Handbook of Transnational Criminal Law. London: Routledge, 2014.

HUGGINS, Martha K. Polícia e política: relações Estados Unidos/América Latina. São Paulo: Cortez, 1998.

HUNTINGTON, Samuel P. Transnational organizations in world politics. World Politics, v. 25, n. 3, p. 334-368, 1973.

IANNI, Octavio. Teorias da globalização. 5. ed. Rio de Janeiro: Civilização Brasileira, 1999.

IUZZOLINO, Gabriele. Le squadre investigative comuni. In: ARMONE, Giovanni M. et al. Diritto penale europeo e ordinamento italiano: le decisioni quadro dell'Unione europea: dal mandato d'arresto alla lotta al terrorismo. Milano: Giuffrè, 2006.

JARDIM, Afrânio Silva. Estudos sobre os pressupostos processuais (processo penal). In: JARDIM, Afrânio Silva. Direito processual penal. 8. ed. Rio de Janeiro: Forense, 1999.

JORNAL OFICIAL, n. C 340, 10 nov. 1997, p. 0001-0144. Disponível em: <http://eur-lex.europa.eu/legal-content/PT/TXT/?uri=CELEX: 12002M030>. Acesso em: 27 set. 2016.

JOUANNET, Emmanuelle Tourme. A short introduction to international law. Cambridge, UK: Cambridge University Press, 2014.

JOUBERT, Chantal; BEVERS, Hans. Schengen investigated: a comparative interpretation of the Schengen provisions on international police cooperation in the light of the European Convention on Human Rights. The Hague: Martinus Nijhoff Publishers, 1996.

KALBI, Luigi. 'Spazio europeo di giustizia' e procedimento penale italiano: adattamenti normativi e approdi giurisprudenziali. Torino: Giappichelli, 2012.

KAUNERT, Christian; LEONARD, Sarah; OCCHIPINTI, John (Ed.). Justice and home affairs agencies in the European Union. London: Routledge, 2016.

KELSEN, Hans. Teoria pura do direito. Tradução de João Baptista Machado. 6. ed. 3a. tiragem. São Paulo: Martins Fontes, 1999.

. Les rapports entre le droit interne et le droit international public. La Haye: Académie de Droit International de La Haye, 1926. t. 14. (Serie Recueil de cours). 
KEOHANE, Robert Owen. NYE, Joseph S. Transnational relations and world politics. Cambridge, Mass.: Harvard University Press, 1972.

KETHINENI, Sesha. Comparative and International Policing, Justice, and Transnational Crime. 2nd. ed. 2014.

LA GRECA, Giuseppe; MARCHETTI, Maria Riccarda. Rogatorie penali e cooperazione giudiziaria Internazionale. Turin: Giappichelli, 2003.

LAHTI, Raimo. Sub-regional co-operation in criminal matters: the experience of the Nordic countries. In: ESER, Albin; LAGODNY, Otto. Principles and procedures for a new transnational criminal law. Freiburg: Society for the Reform of Criminal Law and Max Planck Institute for Foreign and International Criminal Law, 1992.

Towards a rational and humane criminal policy? Trends in Scandinavian penal thinking. Journal of Scandinavian Studies in Criminology and Crime Prevention, v. 1, n. 2, p. 141-155, 2000.

Towards a rational and humane criminal policy? Trends in Scandinavian penal thinking. Journal of Scandinavian Studies in Criminology and Crime Prevention, v. 1, n. 2, p. 141-155, 2000.

LASZLOCZKY, Paolo. La cooperazione internazionale negli atti d'istruzione penale. Padova: Cedam, 1980.

LESSA, Luiz Fernando Voss Chagas. Persecução penal e cooperação internacional direta pelo Ministério Público. Rio de Janeiro: Lumen Juris, 2013.

LIEBMAN, Enrico Tullio. Estudos sobre o processo civil brasileiro. Araras: Bestbook, 2001.

LILLICH, Richard B. The Soering Case. American Journal of International Law, v. 85, n. 1, p. 128-149, 1991.

LIPPA, Alison V. The legality, efficacy, and future use of international executive agreements: an analysis of agreements in criminal matters. Am. Crim. L. Rev., v. 29, n. 4, p. 1301-1348, 1991.

LOPES JÚNIOR, Aury; GLOECKNER, Ricardo Jacobsen. Sistemas de investigação preliminar no processo penal. 6. ed. São Paulo: Saraiva, 2014.

LYONS, Timothy. EC customs law. Oxford: Oxford University Press, 2001.

MANGIARACINA, Annalisa. Verso nuove forme di cooperazione giudiziaria: le squadre investigative comuni. Cassazione Penale, n. 6, p. 2189-2200, 2004.

MARÍN, María Ángeles Pérez. La lucha contra la criminalidad en la Unión Europea: el camino hacia una jurisdicción penal común. Barcelona: Atelier, 2013.

MARINONI, Luiz Guilherme. Teoria geral do processo. 3. ed. São Paulo: Revista dos Tribunais, 2008. 
MARTíN DIZ, F. Los Equipos Conjuntos de Investigación como técnica de cooperación procesal en la Unión Europea. Revista del Poder Judicial, n. 78, p. 89140, 2005.

MARTIN, Richard A. Problems in International Law Enforcement. Fordham International Law Journal, v. 14, p. 519-539, 1990.

MARZAGÃO JR., Laerte; GRECO, Alessandra Orcesi Pedro. Tráfico de pessoas. São Paulo: Quartier Latin, 2010.

MCDANIEL, John. Rethinking police accountability and transparency within the EU: reconciling national and supranational approaches. 2015. Thesis (Doctorate) University of Kent Canterbury, 2015.

MELLO, Celso Duvivier de Albuquerque. Direito internacional público. 15. ed. Rio de Janeiro: Renovar, 2004. v. 1.

. O $\S 2^{\circ}$ do art. $5^{\circ}$ da Constituição Federal. In: TORRES, Ricardo Lobo (Org.). Teoria dos direitos fundamentais. Rio de Janeiro: Renovar, 1999.

MENDES, Gilmar Ferreira; COELHO, Inocêncio Mártires; BRANCO, Paulo Gustavo Gonet. Curso de direito constitucional. São Paulo: Saraiva, 2007.

MENDRONI, Marcelo Batlouni. Crime organizado: aspectos gerais e mecanismos legais. 4. ed. São Paulo: Atlas, 2012.

MILITELLO, Vincenzo; PAOLI, Letizia; ARNOLD, Jorg. I/ crimine organizzato come fenomeno transnazionale: forme di manifestazione, prevenzione e repressione in Italia, Germania e Spagna. Milano: Giuffrè, 2000.

MILLER, Marcello. Título II: Dos limites da Jurisdição nacional e da cooperação internacional (arts. 22 a 41). In: CABRAL, Antonio do Passo; CRAMER, Ronaldo (Coord.). Comentários ao novo código de processo civil. Rio de Janeiro: Forense, 2015.

MIRANDA RODRIGUES, Anabela. A globalização do direito penal - da pirâmide à rede ou entre a unificação e a harmonização. In: emergente. Coimbra: Coimbra, 2008. O direito penal europeu . O direito penal europeu emergente. Coimbra: Coimbra, 2008.

MITSILEGAS, Valsamis. From national to global, from empirical to legal: the ambivalent concept of transnational organized crime. In: BEARE, Margaret. E. Critical reflections on transnational organized crime, money laundering and corruption. Toronto: University of Toronto Press, 2003.

; ALLDRIDGE, Peter; CHELIOTIS, Leonidas (Ed.). Globalisation, criminal law and criminal justice: theoretical, comparative and transnational perspectives. Bloomsbury Publishing, 2015. 
MORÁN BLANCO, Maria del Sagrario; ROPERO CARRASCO, Julia; GARCíA SÁNCHEZ, Beatriz. Instrumentos internacionales en la lucha contra la delincuencia organizada. Madrid: Dykinson, 2011.

MORO, Sérgio Fernando. Cooperação jurídica internacional em casos criminais: considerações gerais. In: BALTAZAR JUNIOR, José Paulo; LIMA, Luciano Flores de. Cooperação jurídica internacional em matéria penal. Porto Alegre: Verbo Jurídico, 2010.

MOYE, Marcel. Le droit des gens moderne. Paris: Recueil Sirey, 1928.

MUELLER, Gerhard O. W. Transnational crime: definitions and concepts. In: WILLIAMS, Phil; VLASSIS, Dimitri. Combating transnational crime: concepts, activities and responses. London; Portland: Frank Cass, 2001.

Transnational crime: an experience in uncertainties. In: EINSTEIN S. AMI, M. Organized crime: uncertainties and dilemmas. Chicago: University of Illinois at Chicago, 1999.

NADELMANN, Ethan A. Cops across borders: the Internationalisation of US Criminal Law Enforcement. Pennsylvania: Pennsylvania State University Press, University Park, 1993.

Global prohibition regimes: the evolution of norms in international society. International Organization, v. 44, n. 4, p. 479-526, 1990.

NAGY, Judit. About joint investigation teams in a nutshell. Current Issues of Business \& Law, v. 4, p. 141-159, 2009.

NAÍM, Moisés. llícito: o ataque da pirataria, da lavagem de dinheiro e do tráfico à economia global. São Paulo: Zahar, 2006.

NEISTEIN, Mariângela Lopes. O agente infiltrado como meio de investigação. 2006. 166 f. Dissertação (Mestrado) - Faculdade de Direito da Universidade de São Paulo, 2006.

NERY JUNIOR, Nelson. Teoria geral dos recursos. 7. ed. São Paulo: Revista dos Tribunais, 2014.

NYE, Joseph S.; KEOHANE, Robert Owen. Transnational relations and world politics: an introduction. International Organization, v. 25, n. 3, p. 329-349, 1971.

OBOKATA, Tom. Transnational organised crime in international law. London: Bloomsbury Publishing, 2010.

OLIVO, Riccardo. Rogatorie e assunzione diretta di testi all'estero (a proposito dell'accordo Italia-USA per il caso "Lockheed"). Rivista Italiana di Diritto e Procedura Penale, an. 19, n. 3, p. 901-904, 1976.

OPPENHEIM, Lassa Francis Lawrence. International law: a treatise - peace. Ed. by Ronald F. Roxburgh. 3th. ed. New York: Longmans Green and Co., 1920. v. 1. 
PAKES, Francis J. Globalisation and the challenge to criminology. New York: Routledge, 2012.

PALUDO, Januário; LIMA, Carlos Fernando; ARAS, Vladimir. Forças-tarefas: direito comparado e legislação aplicável. Brasília: ESMPU, 2011.

PARRA GARCÍA, Javier Luis. El nuevo régimen de las solicitudes de asistencia judicial en materia penal. Cuadernos de Derecho Judicial, n. 13, p. 109-158, 2003.

PATALANO, Vicenzo. Nuove strategie per la lotta al crimine organizzato transnazionale. Torino: Giappichelli, 2003.

PELLET, Alain; DINH, Nguyen Quoc; DAILLIER, Patrick. Direito internacional público. Lisboa: Calouste Gulbenkian, 2003.

PEREIRA, Flávio Cardoso. A moderna investigação criminal: infiltrações policiais, entregas controladas e vigiadas, equipes conjuntas de investigação e provas periciais de inteligência. In: CUNHA, Rogério Sanches; TAQUES, Pedro; GOMES, Luiz Flávio (Coord.). Limites constitucionais da investigação. São Paulo: Revista dos Tribunais, 2009.

PÉREZ GIL, Julio. Equipos conjuntos de investigación penal. In: BULNES, Mar Jimeno. La cooperación judicial civil y penal en el ámbito de la Unión Europea: instrumentos procesales. Barcelona: Bosch, 2007.

PERLINGEIRO, Ricardo. Cooperação jurídica internacional. In: TIBÚRCIO, Carmen; BARROSO, Luís Roberto (Org.). O direito internacional contemporâneo. Rio de Janeiro: Renovar, 2006.

PIERINI, Jean Paul; PASQUA, Giovanni. Police cooperation in the European Union: an overview. In: BASSIOUNI, Cherif; MILITELLO, Vincenzo; SATZGER, Helmut (Ed.). European cooperation in penal matters: issues and perspectives: lectures and materials of the specialization courses in European criminal law. Padova: Cedam, 2008.

PIMENTA BUENO, José Antonio. Apontamentos sobre o processo criminal brasileiro. Ed. anotada, atualizada e complementada por José Frederico Marques. São Paulo: Revista dos Tribunais, 1959.

PIOVESAN, Flávia. Direitos humanos e o direito constitucional internacional. 15. ed. São Paulo: Saraiva, 2015.

. Direitos humanos e o direito constitucional internacional. 14. ed. São Paulo: Saraiva, 2013.

PISANI, Mario. Criminalità organizzata e cooperazione internazionale. In: PISANI, Mario. Nuovi temi e casi di procedura penale internazionale. Milano: LED, 2007.

Nuovi temi e casi di procedura penale internazionale. Milano: LED, 2007.

PITOMBO, Antonio Sérgio Altieri de Moraes. Organização criminosa: nova perspectiva do tipo legal. São Paulo: Revista dos Tribunais, 2009. 
PLACHTA, Michael. Joint investigation teams: a new form of international cooperation in criminal matters. European Journal of Crime, Criminal Law and Criminal Justice, v. 13, n. 2, p. 284-302, 2005.

POCAR, Fausto. L'esercizio non autorizzato del potere statale in territorio straniero. Pádova: CEDAM, 1974.

POLITIS, Nicolas. Le problème des limitations de la souveraineté et la théorie de l'abus des droits dans les rapports internationaux. La Haye: Académie de Droit International de La Haye, 1925. v. 06. (Recueil des cours).

PONTEDURO, Silvia. Le squadre investigative comuni sovranazionali: un nuovo strumento di cooperazione giudiziaria e di polizia. Cassazione Penale, v. 52, n. 10, p. 3566-3573, 2012.

PONTI, Christian. Crimini transnazionali e diritto internazionale. Milano: Giuffrè, 2010.

RAFARACI, Tommaso. La cooperazione di polizia e giudiziaria in materia penale nell'Unione europea dopo il Trattato di Lisbona. Milano: Giuffrè, 2011.

RANGEL, Vicente Marotta. Os conflitos entre o direito interno e os tratados internacionais. Revista da Faculdade de Direito - Universidade de São Paulo, v. 62, n. 2, p. 81-134, 1966.

RASCOVSKI, Luiz. Entrega vigiada: meio investigativo de combate ao crime organizado. São Paulo: Saraiva, 2013.

REBECCHI, Maria Cecilia. Joint investigation teams: a reachable solution to catch unreachable criminals. Queen Mary Law Journal, v. 08, p. 95-108, 2016.

REDO, S. The United Nations criminal justice system in the suppression of transnational crime. In: BOISTER, Neil; CURRIE, Robert J. (Ed.). Routledge Handbook of Transnational Criminal Law. London: Routledge, 2014.

REICHEL, Philip. Handbook of transnational crime and justice. New York: Sage publications, 2005.

; ALBANESE, Jay (Ed.). Handbook of transnational crime and justice. London: Sage Publications, 2013.

REZEK, Francisco. Direito dos tratados. Rio de Janeiro: Forense, 1984.

RICCIOLI, Francesco D. L'accordo tra Italia e Stati Uniti per la reciproca assistenza giudiziaria nell'afare "Lockheed". Rivista di Diritto Internazionale, v. LX, p. 540-565, 1977.

RICO, Ana María Lourido. La asistencia judicial penal en la Unión Europea. Valencia: Tirant lo Blanch, 2004. 
RIJKEN, Conny. Joint investigation teams: principles, practice, and problems lessons learnt from the first efforts to establish a JIT. Utrecht Law Review, v. 2, n. 2, p. 99-118, Dec. 2006.

; VERMEULEN, Gert. Joint investigation teams in the European Union: from theory to practice. The Hague: T. M. C. Asser Press, 2006.

. The legal and practical implementation of JITs: the bumpy road from EU to Member State level. In: RIJKEN, Connie; VERMEULEN, Gert. Joint investigation teams in the European Union: from theory to practice. The Hague: $\mathrm{T}$. M. C. Asser Press, 2006.

RIPOLLÉS, Antonio Quintano. Tratado de derecho penal internacional e internacional penal. Madrid: Consejo Superior de Investigaciones Cientificas, Instituto Francisco de Vitoria, 1957.

RISTAU, Bruno A. International Cooperation in Penal Matters: The Lockheed Agreements. Michigan Yearbook of International Legal Studies, v. 4, 1983.

ROSENAU, James N. The study of global interdependence: essays on the transnationalization of world affairs. New York: Nichols Publishing Company, 1980.

ROTH, Mitchel P. Historical overview of transnational crime. In: REICHEL, Philip; ALBANESE, Jay (Ed.). Handbook of transnational crime and justice. London: Sage Publications, 2013.

ROUX, Jean André (Ed.). Premier Congrès de police judiciaire internationale: Monaco, avril 1914. Paris: Librairie Générale de Jurisprudence Marchal et Billard, G. Godde, 1926.

RUGGERI, Stefano. Transnational evidence and multicultural inquiries in Europe. London: Springer, 2014.

SALAZAR, Lorenzo. La lotta alla criminalità nell'Unione: passi in avanti verso uno spazio giudiziario comune prima e dopo la Costituzione per l'Europa ed il Programma dell'Aia. Cassazione Penale, v. 44, n. 11, p. 3510-3537, 2004.

SALGADO, Daniel; QUEIROZ, Ronaldo. A prova no enfrentamento à macrocriminalidade. Salvador: Juspodivm, 2015.

SÁNCHEZ, Jesús María Silva. La expansión del derecho penal: aspectos de la política criminal en las sociedades posindustriales. Madrid: Civitas, 2001.

SANTOS, Boaventura de Sousa. Os processos de globalização. In: SANTOS, Boaventura de Sousa (Org.). A globalização e as ciências sociais. São Paulo: Cortez, 2005.

(Org.). A globalização e as ciências sociais. São Paulo: Cortez, 2005.

SCARCELLA, Alessio (Ed.). Prelievo del DNA e banca dati nazionale: il proceso penale tra accertamento del fatto e cooperazione internazionale. Padova: Cedam, 2009. 
SCELLA, Andrea. Verso le squadre investigative comuni: lo scenario italiano. In: RAFARACI, Tommaso. La cooperazione di polizia e giudiziaria in materia penale nell'Unione europea dopo il Trattato di Lisbona. Milano: Giuffrè, 2011.

SCHABAS, William A. An introduction to the international criminal court. Cambridge: Cambridge University Press, 2011.

SCHACHTER, Oscar. International law in theory and practice: general course in public international law. La Haye: Académie de Droit International de La Haye, 1982. v. 178. (Recueil des cours).

SCHALKEN, Tom; PRONK, Maarten. On joint investigation teams, Europol and supervision of their joint actions. European Journal of Crime Criminal Law and Criminal Justice, v. 10, n. 1, p. 70-82, 2002.

SCHÜNEMANN, Bernd. Solution models and principles governing the transnational evidence-gathering in the EU. In: RUGGERI, Stefano. Transnational evidence and multicultural inquiries in Europe. London: Springer, 2014.

SCHÜTTE, Sofie Arjon. Government policies and civil society initiatives against corruption. In: BUNTE, Marco; UFEN, Andreas (Ed.). Democratization in PostSuharto Indonesia. London: Routledge, 2008.

SCOTT, James Brown. Law, the State, and the International Community. New York: Columbia University Press, 1939.

(Ed.). Selections from Three Works of Francisco Suárez. The Classics of International Law. Oxford: Clarendon Press, 1944. v. 2.

SERRANO, Amaya Arnaiz. Evolución de la cooperación judicial penal internacional: en especial, la cooperación judicial en Europa. In: CARMONA RUANO, M.; GONZÁLEZ VEGA, I. U.; MORENO CATENA, V. (Dir.). Cooperación judicial penal en Europa. Madrid: Dykinson, 2013.

SERRANO, Mónica. Transnational organized crime and international security: business as usual? In: BERDAL, Mats R.; SERRANO, Mónica. Transnational organized crime and international security: business as usual? Boulder, Co.: Lynne Rienner Publishers, 2002.

SERRANO, Nicolás González-Cuéllar; HERMIDA, Ágata M. Sanz; PRADILLO; Juan Carlos Ortiz. Problemas actuales de la justicia penal: secreto profesional, cooperación jurídica internacional, víctimas de delitos. Madrid: Colex, 2013.

SHAW, Malcolm N. Direito internacional. São Paulo: Martins Fontes, 2010.

SILVA, Ovídio Araújo Baptista da. Curso de processo civil. vol. I. 6. ed. São Paulo: Revista dos Tribunais, 2003. v. I.

SMALL, Kevonne; TAYLOR, Bruce. State and local law enforcement response to transnational crime. Trends in Organized Crime, v. 10, n. 2, p. 5-17, 2006. 
SOARES, Gustavo Torres. Investigação criminal e inovações técnicas e tecnológicas. Belo Horizonte: D'Plácido, 2016.

SPAPENS, Toine. Joint investigation teams in the European Union: article 13 JITS and the alternatives. Eur. J. Crime Crim. L. \& Crim. Just., v. 19, n. 3, p. 239-260, 2011.

SPIEZIA, Filippo. Coordinamento delle indagini ed Eurojust. In: KALBI, Luigi. 'Spazio europeo di giustizia' e procedimento penale italiano: adattamenti normativi e approdi giurisprudenziali. Torino: Giappichelli, 2012.

SUÁREZ, Francisco. On laws and God the lawgiver. In: SCOTT, James Brown (Ed.). Selections from Three Works of Francisco Suárez. The Classics of International Law. Oxford: Clarendon Press, 1944. v. 2.

TELLES JÚNIOR, Goffredo. Iniciação na ciência do direito. São Paulo: Saraiva, 2001.

TERÁN, Roberto Álvarez. Metodologías de investigación transfronteriza contra la trata de personas en la Comunidad Andina y el Mercosur. In: SEGUNDO ENCUENTRO NACIONAL DE TRATA Y TRÁFICO DE PERSONAS. 10 junio 2014. Anales... Perú, 2014. Disponível em: <du.pe/wp-content/uploads/2014/06/RobertoÁlvarez-Terán-Metodologías-de-Investigación-Transfronteriza-contra-la-Trata-dePersonas-en-la-Comunidad-Andina-y-el-Mercosur.pdf>. Acesso em: 22 dez. 2016.

THEODORO JÚNIOR, Humberto. Pressupostos processuais e condições da ação no processo cautelar. In: WAMBIER, Luiz Rodrigues; WAMBIER, Teresa Arruda Alvim (Orgs.). Doutrinas essenciais: processo civil - teoria geral do processo I. São Paulo: RT, 2014. v. II.

TIBÚRCIO, Carmen; BARROSO, Luís Roberto (Org.). O direito internacional contemporâneo. Rio de Janeiro: Renovar, 2006.

TOMISON, A. M.; STANLEY, J. Social welfare framework: models of collaborative service delivery in child protection. Unpublished report for the South Australian Department of Human Services, 2001. Disponível em: <https://aifs.gov.au/cfca/ publications/strategic-directions-child-protection-informing-policy/brief-3-socialwelfare-framework>. Acesso em: 19 nov. 2016.

TORNAGHI, Hélio. Instituições de processo penal. Rio de Janeiro: Forense, 1959.

TORRES, Ricardo Lobo (Org.). Teoria dos direitos fundamentais. Rio de Janeiro: Renovar, 1999.

TRIEPEL, Heinrich. Les rapports entre le droit interne et le droit international. Haye: Academie de Droit International de La Haye, 1923. t. 1 (Serie Recueil des cours).

TUCCl, Rogério Lauria. Ministério Público e investigação criminal. São Paulo: Revista dos Tribunais, 2004.

VABRES, Henri Donnedieu de. Les principes modernes du droit pénal international. Paris: Librairie du Récueil Sirey, 1928. 
VATTEL, Emmerich. Law of Nations or the Principles of Natural Law. Trad. Charles D. Fenwick. Washington: Carnegie Institution of Washington, 1916.

VENOSA, Sílvio de Salvo. Direito civil. 14. ed. São Paulo: Atlas, 2014. v. 1.

VIEIRA, Manuel Adolfo. Derecho penal internacional y derecho internacional penal. Montevideo: Fundación de Cultura Universitaria, 1969.

VIGONI, Daniela. Dalla rogatoria all'acquisizione diretta. In: LA GRECA, Giuseppe; MARCHETTI, Maria Riccarda. Rogatorie penali e cooperazione giudiziaria Internazionale. Turin: Giappichelli, 2003.

VILLALPANDO, Waldo. Crimen organizado transnacional: características de las redes internacionales. Buenos Aires: Astrea, 2014.

VITALE, Alessandro. Le squadre investigative comuni. In: FILIPPI, Leonardo et al. (Eds.). La circolazione investigativa nello spazio giuridico europeo: strumenti, soggetti, risultati. Padova: Cedam, 2010.

VLASSIS, Dimitri. La Convención de Naciones Unidas contra el crimen transnacional organizado. In: BERDAL, Mats. SERRANO, Mónica (Comp.). Crimen transnacional organizado y seguridad internacional: cambio y continuidad. Ciudad del México: Fondo de Cultura Económica, 2005.

VOGEL, Joachim. Cooperación penal: cinco tendencias. Cinco propuestas para una acción futura. In: ZAPATERO, Luis Arroyo; MARTÍN, Adán Nieto; DE MORALES ROMERO, Marta Muñoz. El derecho penal de la Unión Europea: situación actual y perspectivas de futuro. Cuenca: Ediciones de la Universidad de Castilla La Mancha, 2007.

VUELTA SIMON, Samuel. Dernières nouvelles des équipes communes d'enquête: entre partage et souveraineté. Revue de Science Criminelle et de Droit Pénal Compare, n. 2, p. 267-278, avril/juin 2007.

WAMBIER, Luiz Rodrigues; WAMBIER, Teresa Arruda Alvim (Orgs.). Doutrinas essenciais: processo civil. Revista de Processo, n. 17, p. 41-49, 1980.

São Paulo: RT, 2014. v. II.

Doutrinas essenciais: processo civil - teoria geral do processo I.

WEBER, Patrícia Núñez. A cooperação jurídica internacional em medidas processuais penais. Porto Alegre: Livraria do Advogado, 2011.

WEYEMBERGH, Anne. L'avenir des mécanismes de coopération judiciaire pénale entre les États membres de I'Union européenne. In: DE KERCHOVE, Gilles. Vers un espace judiciaire pénal européen: towards a European judicial criminal area. Bruxelas: Éditions de l'Université de Bruxelles, 2000.

WILLIAMS, P. Organizing transnational crime: networks, markets and hierarchies. In: __ _ VLASSIS, Dimitri. Combating transnational crime: concepts, activities and responses. London; Portland: Frank Cass, 2001. 
WILLIAMS, Phil; VLASSIS, Dimitri. Combating transnational crime: concepts, activities and responses. London; Portland: Frank Cass, 2001.

WOLFF, Christian Freiherr von. Jus gentium methodo scientifica pertractatum. Trad. Joseph H. Drake. Oxford: Clarendon Press, 1934.

WRIGHT, Wynne; MUZZATTI, Stephen L. Not in my port: The "death ship" of sheep and crimes of agri-food globalization. Agriculture and Human Values, v. 24, n. 2, p. 133-145, 2007.

WUNDERLICH, Alexandre; OLIVEIRA, Rodrigo Mores. Resistência, prática de transformação social e limitação do poder punitivo a partir do sistema de garantias: pela (re) afirmação do garantismo penal na contemporaneidade. In: (Coord.). Política criminal contemporânea: criminologia, direito penal e direito processual penal. Porto Alegre: Livraria do Advogado, 2008.

YARSHELL, Flávio Luiz; ZANOIDE DE MORAES, Maurício (Org.). Estudos em homenagem à professora Ada Pellegrini Grinover. São Paulo: DPJ, 2005.

ZAGARIS, Bruce. US International Cooperation against transnational organized crime. Wayne L. Rev., v. 44, p. 1401-1464, 1998.

ZAPATERO, Luis Arroyo; MARTíN, Adán Nieto; DE MORALES ROMERO, Marta Muñoz. El derecho penal de la Unión Europea: situación actual y perspectivas de futuro. Cuenca: Ediciones de la Universidad de Castilla La Mancha, 2007.

ZILLI, Marcos Alexandre Coelho. Os caminhos da internacionalização do processo penal. In: FERNANDES, Antonio Scarance; ZILLI, Marcos Alexandre Coelho. Direito processual penal internacional. São Paulo: Atlas, 2013.

ZÚÑIGA RODRÍGUEZ, Laura. Criminalidad organizada y sistema de derecho penal: contribución a la determinación del injusto penal de organización criminal. Madrid: Comares, 2009.

\section{Legislação, Jurisprudência e Documentos Oficiais}

BRASIL. Câmara Federal. PL no 4.850/2016 [Relatório submetido à Comissão Especial]. Disponível em: <http://www.camara.gov.br/proposicoesWeb/prop mostrarintegra?codteor $=1509814$ \&filename $=\mathrm{SBT}+3+\mathrm{PL} 485016+\% 3 \mathrm{D} \% 3 \mathrm{E}+\mathrm{PL}+48$ 50/2016>. Acesso em: 11 nov. 2016.

<http://www.camara.gov.br/proposicoesWeb/prop mostrarintegra?codteor $=15063$ 14\&filename $=\mathrm{SBT}+1+\mathrm{PL} 485016+\% 3 \mathrm{D} \% 3 \mathrm{E}+\mathrm{PL}+4850 / 2016>$. Acesso em: 11 nov. 2016.

Conselho Nacional de Justiça. Resolução CNJ no 213, de 15 de dezembro de 2015. Dispõe sobre a apresentação de toda pessoa presa à autoridade judicial 
no prazo de 24 horas. Disponível em: <http://www.cnj.jus.br/busca-atosadm?documento=3059>. Acesso em: 13 out. 2016 .

BRASIL. Presidência da República. Código de Processo Civil (Lei no 13.105, de 16 de março de 2015). Disponível em: <http://www.planalto.gov.br/ccivil_03/_ato20152018/2015/lei/l13105.htm>. Acesso em: 6 jan. 2017.

Código de Processo Penal (Decreto-lei no 3.689, de 3 de outubro de 1941). Disponível em: <http://www.planalto.gov.br/ ccivil_03/decretolei/Del3689.htm>. Acesso em: 6 jan. 2017.

Disponível $\quad \begin{aligned} & \text { Constituição da República Federativa do Brasil de } 1988 . \\ & \text { em: }\end{aligned}$ constituicaocompilado.htm>. Acesso em: 6 jan. 2017).

. Decreto no 3.468, de 17 de maio de 2000. Disponível em: <http://www.planalto.gov.br/ccivil_03/decreto/d3468.htm>. Acesso em: 6 jan. 2017.

- Decreto no 3.810, de 2 de maio de 2001. Disponível em: <http://>www.planalto.gov.br/ccivil_03/decreto/2001/D3810.htm>. Acesso em: 6 jan. 2017.

_ _ Decreto-lei no 4.657, de 4 de setembro de 1942. Lei de Introdução às normas do Direito Brasileiro. Disponível em: $<$ https://www.planalto.gov.br/ccivil_03/decreto-lei/Del4657compilado.htm>. Acesso em: 6 jan. 2017.

. Lei no 6.815, de 19 de agosto de 1980. Disponível em: <http://www.planalto.gov.br/ccivil_03/leis/L6815.htm>. Acesso em: 6 jan. 2017.

; Senado. PL no 7.370/2014. Disponível em: <http://legis.senado.leg.br/ mateweb/arquivos/mate-pdf/161378.pdf>. Acesso em: 20 out. 2016.

Projeto de Lei do Senado (PLS) no 479/2012. Disponível em: <http://www.senado.leg.br/atividade/rotinas/materia/getPDF.asp?t=121385\&tp $=1>$. Acesso em: 20 out. 2016 .

Superior Tribunal de Justiça. HC 69694/SP, Relator(a) Maria Thereza de Assis Moura, Sexta Turma, DJE, 17/03/2008.

Regimento Interno. Disponível em: <http://www.stj.jus.br/ publicacaoinstitucional//index.php/Regimento/article/view/725/3024>. Acesso em: 6 jan. 2017.

BRASIL. Supremo Tribunal Federal. ADI 5240. Relator(a): Min. Luiz Fux, Tribunal Pleno, julgado em 20/08/2015, PROCESSO ELETRÔNICO DJe-018 DIVULG 2901-2016 PUBLIC 01-02-2016.

CR 7783, Relator(a): Min. PRESIDENTE, Presidente Min. CELSO $\overline{\mathrm{DE}}$ MELLO, julgado em 02/02/1998, publicado em DJ 16-02-1998 PP-00014. 
BRASIL. Supremo Tribunal Federal. CR 8577, Relator(a): Min. Presidente, Decisão proferida pelo Ministro Celso de Mello, julgado em 19/02/1999, publicada em DJ 01/03/1999 PP-00034.

HC 127483, Relator(a): Min. DIAS TOFFOLI, Tribunal Pleno, julgado em 27/08/2015, PROCESSO ELETRÔNICO DJe-021 DIVULG 03-02-2016 PUBLIC 04-02-2016. Voto: p. 15-19.

HC 72131, Relator(a): Min. Marco Aurélio, Relator(a) p/ Acórdão: Min. Moreira Alves, Tribunal Pleno, julgado em 23/11/1995, DJ 01-08-2003 PP00103 EMENT VOL-02117-40 PP-08650.

HC 89171, Relator(a): Min. MARCO AURÉLIO, Relator(a) p/ Acórdão: Min. MENEZES DIREITO, Primeira Turma, julgado em 24/03/2009, DJe084 DIVULG 07-05-2009 PUBLIC 08-05-2009 EMENT VOL-02359-03 PP-00426 RTJ VOL-00210-01 PP-00274 RT v. 98, n. 886, 2009, p. 479-487, LEXSTF, v. 31, n. 365, 2009.

Inq 2245, Relator(a): Min. Joaquim Barbosa, Tribunal Pleno, julgado em 28/08/2007, DJe-139 DIVULG 08-11-2007 PUBLIC 09-11-2007 DJ 0911-2007 PP-00038 EMENT VOL-02298-01 PP-00001 RTJ VOL-00203-02 PP00473. Nesse mesmo sentido: STF, HC 71039, Relator(a): Min. Paulo Brossard, Tribunal Pleno, julgado em 07/04/1994, DJ 06-12-1996 PP-48708 EMENT VOL01853-02 PP-00278.

Inq 2424, Relator(a): Min. CEZAR PELUSO, Tribunal Pleno, julgado em 26/11/2008, DJe-055 DIVULG 25-03-2010 PUBLIC 26-03-2010 EMENT VOL-02395-02 PP-00341.

. Inq. 4146, Relator(a): Min. Teori Zavascki, Tribunal Pleno, julgado em 22/06/2016, acórdão eletrônico DJe-212 Divulg 04-10-2016 Public 05-10-2016; Petição STF 19.229/2014, Relator(a): Min. Ricardo Lewandowski.

dl/maluf.pdf>. Acesso em: 3 nov. 2016.

Petição 19.229/2014. Disponível em: <http://s.conjur.com.br/ Pleno. Inq. 4146. Relator(a): Min. Teori Zavascki, julgado em 22/06/2016, acórdão eletrônico DJe-212 Divulg 04-10-2016 Public 05-10-2016. Disponível em: <http://redir.stf.jus.br/paginadorpub/ paginador.jsp?docTP=TP\&docID=11786520>. Acesso em: 20 out. 2016.

RE 349703, Relator(a): Min. Carlos Britto, Relator(a) p/ Acórdão: Min. Gilmar Mendes, Tribunal Pleno, julgado em 03/12/2008, DJe-104 DIVULG 0406-2009 PUBLIC 05-06-2009 EMENT VOL-02363-04 PP-00675.

RE 593727, Relator(a): Min. CEZAR PELUSO, Relator(a) p/ Acórdão: Min. GILMAR MENDES, Tribunal Pleno, julgado em 14/05/2015, ACÓRDÃO ELETRÔNICO REPERCUSSÃO GERAL - MÉRITO DJe-175 DIVULG 04-09-2015 PUBLIC 08-09-2015. 
BRASIL. Supremo Tribunal Federal. RE 597368, Relator(a): Min. Ellen Gracie, Relator(a) p/ Acórdão: Min. TEORI ZAVASCKI, Tribunal Pleno, julgado em 15/05/2013, DJe-100 DIVULG 26-05-2014 PUBLIC 27-05-2014 EMENT VOL02732-01 PP-00105.

RHC 79.785/RJ [voto prolatado pelo Min. Sepúlveda Pertence], Rel. Min. Sepúlveda Pertence, DJ de 22/11/2002, p. 295/301. Disponível em: $<$ http://redir.stf.jus.br/paginadorpub/paginador.jsp?docTP=AC\&doclD=102661>. Acesso em: 15 dez. 2016.

RMS 32732 AgR, Relator(a): Min. CELSO DE MELLO, Segunda Turma, julgado em 03/06/2014, PROCESSO ELETRÔNICO DJe-148 DIVULG 31 07-2014 PUBLIC 01-08-2014.

Tribunal Pleno. RE 349703, Relator(a): Min. Carlos Britto, Relator(a) p/ Acórdão: Min. Gilmar Mendes, julgado em 03/12/2008, DJe-104 DIVULG 04-06-2009 PUBLIC 05-06-2009 EMENT VOL-02363-04 PP-00675).

COLOMBIA (Gobierno). Constitución Política de Colombia de 20 de julio de 1991. Disponível em: <http://www.constitucioncolombia.com/indice.php>. Acesso em: 12 out. 2016.

CARTA DAS NAÇÕES UNIDAS (Decreto no 19.841/1945). Disponível em: <https://www.unicef.org/brazil/pt/resources_10134.htm>. Acesso em: 3 jan. 2017.

CONVENÇÃO INTERAMERICANA SOBRE ASSISTÊNCIA MÚTUA EM MATÉRIA PENAL. Promulgada no Brasil pelo Decreto no 6.340, de 3 de janeiro de 2008. Disponível em: <http://www.oas.org/juridico/portuguese/treaties/A-55.htm>. Acesso em: 23 set. 2016.

CONVENÇÃO RELATIVA À ASSISTÊNCIA MÚTUA E À COOPERAÇÃO ENTRE AS ADMINISTRAÇÕES ADUANEIRAS (NÁPOLES II). Jornal Oficial, n. C 024 de 23 jan. 1998. Disponível em <http://eur-lex.europa.eu/legal-content/PT/TXT/?uri= celex:41998A0123(01)>. Acesso em: 8 jan. 2017.

CONVENTION FRANCO-SUISSE, DE 23 DE FEVEREIRO DE 1882. Journal du Palais: lois, décrets, règlements et instructions, tome 74, Paris, 1863. Disponível em: <http://gallica.bnf.fr/ark:/12148/bpt6k55181328>. Acesso em: 10 nov. 2016.

COUNCIL OF THE EUROPEAN UNION. Joint Investigation Teams Manual. Prepared in the framework of the joint JITs Project of Eurojust and Europol. Disponível em: <https://www.europol.europa.eu/sites/default/files/st15790re01.en11.pdf>. Acesso em: 18 set. 2016.

DRAFT DECLARATION ON RIGHTS AND DUTIES OF STATES DE 1949. Disponível em: <http://www.bits.de/ac-archive/voelkerrecht/on/declar.htm>. Acesso em: 3 jan. 2017.

ECHR: Case of Soering v. The United Kingdom (application no. 14038/88), julgado em 07/07/1989. Disponível em: <http://hudoc.echr.coe.int/eng?i=001-57619. Acesso em: 24 nov. 2016. 
EUR-LEX. Agreement on Mutual Legal Assistance between the European Union and the United States of America. Disponível em: <http://eurlex.europa.eu/LexUriServ/LexUriServ.do?uri=OJ:L:2003:181:0034: 0042:en:PDF>. Acesso em: 15 set. 2016.

. Council Resolution of 26 February 2010 on a Model Agreement for setting up a Joint Investigation Team (2010/C 70/01). Disponível em: <http://eurlex.europa.eu/homepage.html>. Acesso em: 18 set. 2016.

EUROPOL; EUROJUST. Guide on EU Member States' Legislation on Joint Investigation Teams. Disponível em: <http://jit-thb.pccseesecretariat.si/ index.php?page=static\&item=32>. Acesso em: 18 set. 2016.

(JITs Network). Disponível em: <http://www.eurojust.europa.eu/ Practitioners/JITs/jitsnetwork/Pages/JITs-network.aspx>. Acesso em: 18 set. 2016.

FRANCE. Assemblee Nationale. Constitution du 4 octobre 1958. Disponível em: <http://www.assemblee-nationale.fr/connaissance/constitution.asp>. Acesso em: 12 out. 2016.

UNITED NATIONS OFFICE ON DRUGS AND CRIME. Informal Expert Working Group on Joint Investigations: Conclusions and Recommendations (CTOC/COP/2008/CRP.5). Disponível em: <https://www.unodc.org/documents/ treaties/COP2008/crp5.pdf>. Acesso em: 15 out. 2016.

RELATÓRIO EXPLICATIVO SOBRE A CONVENÇÃO, DE 29 DE MAIO DE 2000. Jornal Oficial, n. C 379, de 29 dez. 2000, p. 0007-0029. Disponível em: <http://eurlex.europa.eu/oj/direct-access.html>. Acesso em: 15 set. 2016.

REPORTS OF INTERNATIONAL ARBITRAL AWARDS, v. II, 1928. Disponível em: <http://legal.un.org/riaa/vol_2.shtml>. Acesso em: 20 dez. 2016.

REPORT OF THE OPEN-ENDED INTERGOVERNAMENTAL EXPERT GROUP MEETING ON THE PREPARATION OF A DRAFT CONVENTION AGAINST ILLICIT TRAFFIC IN NARCOTIC DRUGS AND PSYCHOTROPIC SUBSTANCES (E/CN.7/1988/2 Part II - $\S \S 150$ a 154. Disponível em: <http://daccessods.un.org/access.nsf/Get?Open\&DS=E/CN.7/1988/2 (Partll)\&Lang=E>. Acesso em: 13 set. 2016.

REPORT OF THE UNITED NATIONS HIGH COMMISSIONER FOR HUMAN RIGHTS: situation of human rights and the activities of the United Nations Joint Human Rights Office in the Democratic Republic of the Congo - A/HRC/30/32. Disponível em: <http://ap.ohchr.org/documents/alldocs.aspx?doc_id=25600>. Acesso em: 8 dez. 2016.

REVISED DRAFT UNITED NATIONS CONVENTION AGAINST TRANSNATIONAL ORGANIZED CRIME (A/AC.254/4/Rev.5). Disponível em: <https://www.unodc.org/ unodc/en/treaties/CTOC/background/session6.html>. Acesso em: 28 set. 2016. 
SEGUNDO ENCUENTRO NACIONAL DE TRATA Y TRÁFICO DE PERSONAS. 10 junio 2014. Anales... Perú, 2014. Disponível em: <du.pe/wp-content/uploads/2014/ 06/Roberto-Álvarez-Terán-Metodologías-de-Investigación-Transfronteriza-contrala-Trata-de-Personas-en-la-Comunidad-Andina-y-el-Mercosur.pdf>. Acesso em: 22 dez. 2016.

TRATADO DA UNIÃO EUROPEIA - Protocolo no 36 relativo às disposições transitórias. Disponível em: <http://eur-lex.europa.eu/oj/direct-access.html>. Acesso em: 15 set. 2016.

TRAVAUX PRÉPARATOIRES OF THE NEGOTIATIONS FOR THE ELABORATION OF THE UNITED NATIONS CONVENTION AGAINST CORRUPTION. Disponível em: <https://www.unodc.org/unodc/en/treaties/CAC/ travaux-preparatoires.html>. Acesso em: 13 set. 2016.

UNITED NATIONS. Draft United Nations Convention against Transnational Organized Crime (A/AC.254/4). Disponível em: <https://www.unodc.org/unodc/ en/treaties/CTOC/background/session1.html>. Acesso em: 28 set. 2016.

. Draft United Nations framework Convention against Organized Crime. Disponível em: <http://www.un.org/documents/ga/docs/51/c3/ac351-7.htm>. Acesso em: 28 set. 2016.

U. S. DEPARTMENT OF STATE. United States Treaties and other International Agreements, v. 27, parte 4, 1976.

1976-1977.

. United States Treaties and other International Agreements, v. 28, parte 2, 1979.

. United States Treaties and other International Agreements, v. 27, parte 1,

UNITED NATIONS DEPARTMENT OF PEACEKEEPING OPERATIONS AND DEPARTMENT OF FIELD SUPPORT. Civil Affairs Handbook. New York: United Nations, 2012.

UNITED NATIONS OFFICE ON DRUGS AND CRIME (ESCRITÓRIO DAS NAÇÕES UNIDAS SOBRE DROGAS E CRIME. UNODC: Regional Programme Office for South Eastern Europe. Disponível em: <https://www.unodc.org/ documents/southeasterneurope/Guidelines-English.pdf>. Acesso em: 19 out. 2016.

UNITED NATIONS OFFICE ON DRUGS AND CRIME (ESCRITÓRIO DAS NAÇÕES UNIDAS SOBRE DROGAS E CRIME). Model Legislative Provisions against Organized Crime. Disponível em: <https://www.unodc.org/unodc/en/ organized-crime/tools-and-publications.html>. Acesso em: 19 out. 2016. 


\section{Links/sites consultados}

http://archives.eui.eu/en/fonds/154688?item=JFRM-02.01-4

http://dai-mre.serpro.gov.br/atos-internacionais/multilaterais/acordo-quadro-decooperacao-entre-os-estados-partes-do-mercosul-e-estados-associados-para-acriacao-de-equipes-conjuntas-de-investigacao-22-10/

http://data.consilium.europa.eu/doc/document/ST-6667-1999-INIT/en/pdf

http://eur-lex.europa.eu/collection/eu-law.html

http://eur-lex.europa.eu/legal-content/EN/TXT/HTML/?uri=CELEX:22004A0129 (01)\&from $=$ EN

http://eur-lex.europa.eu/legal-content/PT/TXT/?uri=CELEX\%3A42000A0712(01)

http://eur-lex.europa.eu/legal-content/PT/TXT/HTML/?uri=CELEX:42000A0922 (02)\&from $=\mathrm{EN}$

http://eur-lex.europa.eu/oj/direct-access.html

http://gallica.bnf.fr/ark:/12148/bpt6k91227n/f4.image

http://legal.un.org/riaa/cases/vol_II/1239-1305.pdf

http://legal.un.org/riaa/cases/vol_XI/243-255.pdf

http://legis.senado.gov.br/legislacao/ListaPublicacoes.action?id=115928

http://register.consilium.europa.eu/doc/srv?l=EN\&f=ST\%2010900\%202005\%20INI $\mathrm{T}$

http://repository.un.org

http://silep.vicepresidencia.gob.bo/ SILEP/masterley/118405

http://www.asambleanacional.gob.ec/es/legislamos/tratados_e_instrumentos_inter nacionales_que_no_requieren_aprobacion_previa_de_la_asamblea

http://www.brasil.gov.br/economia-e-emprego/2016/12/itamaraty-confirma-

suspensao-da-venezuela-do-mercosul>.

http://www.camara.gov.br/proposicoesWeb/prop_emendas;jsessionid=31B10EC9 BE4AEC7EF1558FAAEDE72310. proposicoesWeb1 ?idProposicao=611445\&subst $=0$

http://www.camara.gov.br/proposicoesWeb/prop_mostrarintegra?codteor $=150631$

4\&filename $=S B T+1+P L 485016+\% 3 D \% 3 E+P L+4850 / 2016$ 
http://www.camara.leg.br/internet/sitaqweb/TextoHTML.asp?etapa=11\&nuSessao $=0923 / 14$

http://www.camera.it/parlam/leggi/01367I.htm

http://www.coe.int/en/web/conventions/full-list/-/conventions/treaty/182

http://www.coe.int/en/web/portal/47-members-states

http://www.comjib.org/contenido/comjib

http://www.comjib.org/contenido/entrada-en-vigor-del-convenio-iberoamericanosobre-el-uso-de-la-videoconferencia-en-la-coo>

http://www.comjib.org/eventos/se-firma-el-convenio-iberoamericano-sobre-el-usode-la-videoconferencia-en-la-cumbre-de-jefe

http://www.comjib.org/node/1263

http://www.comjib.org/sites/default/files/Convenio_Cooperacion_ECI_Firmado_PT. PDF

http://www.comjib.org/sites/default/files/Marco\%20Normativo.pdf

http://www.consilium.europa.eu/ueDocs/cms_Data/docs/polju/en/EJN220.pdf

http://www.consilium.europa.eu/uedocs/cms_data/docs/polju/en/ejn360.pdf

http://www.ejn-crimjust.europa.eu/ejn/EJN_FichesBelges.aspx\#

http://www.eurojust.europa.eu/Practitioners/JITs/jitsnetwork/Pages/JITs-

meetings.aspx

http://www.europarl.europa.eu/summits/tam_pt.htm

http://www.fatf-gafi.org/about/membersandobservers/

http://www.fatf-gafi.org/media/fatf/documents/recommendations/pdfs/FATF-40-

Rec-2012-Portuguese-Port.pdf

http://www.fatf-gafi.org/publications/fatfrecommendations/ $\mathrm{hf}=10 \& \mathrm{~b}=0 \& \mathrm{~s}=\mathrm{desc}$

(fatf_releasedate)

http://www.gddc.pt/cooperacao/materia-penal/textos-mpenal/ce/ConsEuropaRar 18-2006.htm

http://www.gddc.pt/siii/docs/rar63-2001.pdf

http://www.governo.it/sites/governo.it/files/testo_34.pdf

http://www.icj-cij.org/pcij/serie_A/A_01/03_Wimbledon_Arret_08_1923.pdf

http://www.icj-cij.org/pcij/serie_A/A_10/30_Lotus_Arret.pdf 
http://www.icj-cij.org/pcij/serie_AB/AB_41/01_Regime_douanier_Avis_ consultatif.pdf

http://www.legislation.gov.uk/ukpga/2000/23/contents

http://www.mercosur.int/innovaportal/file/4827/1/acuerdosobreequiposconjuntospo rtugues.pdf

http://www.mre.gov.py/tratados/public_web/ConsultaMercosur.aspx

http://www.na.gov.pk/uploads/documents/1365050846_309.pdf

http://www.norden.org/en/om-samarbejdet-1/nordic-agreements/treaties-andagreements

http://www.oas.org/dil/port/tratados_A-

41_Carta_da_Organiza\%C3\%A7\%C3\%A3o_dos_Estados_Americanos.pdf http://www.oas.org/pt/sla/dlc/remja/pdf/ remja_x_rec_conc_po.pdf http://www.pccseesecretariat.si/index.php?page=documentspcc\&item =35 http://www.planalto.gov.br/ccivil_03/decreto/1990-1994/d0592.htm http://www.poderjudicial.gob.ni/pjupload/comjib/Perfil_Proyecto.pdf http://www.scm.oas.org/idms_public/PORTUGUESE/Hist_14/MJ00695P04.doc http://www.un.org/en/documents/index.html.

http://www.un.org/en/ga/search/view_doc.asp?symbol=S/RES/138(1960) http://www.un.org/en/sections/un-charter/chapter-i/ http://www.un-documents.net/a25r2625.htm http://www.unodc.org/cld/index-sherloc-leg.jspx https://documents.un.org/prod/ods.nsf/home.xsp https://treaties.un.org https://treaties.un.org/Pages/showDetails.aspx?objid=080000028011c2d7 https://www.admin.ch/opc/it/classifiedcompilation/19060002/190605250000/0.742. 140.26.pdf https://www.admin.ch/opc/it/classified-compilation/20030827/index.html https://www.boe.es/buscar/pdf/2003/BOE-A-2003-10288-consolidado.pdf https://www.boe.es/diario_boe/ txt.php?id=BOE-A-2009-14647 
https://www.dhs.gov/news/2011/12/06/fact-sheet-beyond-border-united-states\%E2\%80\%93-canada-law-enforcement-cooperation

https://www.europol.europa.eu/content/agreement-between-eurojust-and-europol https://www.europol.europa.eu/sites/default/files/st15790-re01.pt11.pdf https://www.planalto.gov.br/ccivil_03/decreto-lei/Del4657compilado.htm https://www.unodc.org/congress/en/previous/previous-05.html https://www.unodc.org/congress/en/previous/previous-09.html https://www.unodc.org/unodc/en/treaties/ https://www.unodc.org/unodc/en/treaties/CTOC/travaux-preparatoires.html 


\section{ANEXOS}

A - ACORDO QUADRO DE COOPERAÇÃO ENTRE OS ESTADOS PARTES DO MERCOSUL E ESTADOS ASSOCIADOS PARA A CRIAÇÃO DE EQUIPES CONJUNTAS DE INVESTIGAÇÃO

B - CONVÊNIO PARA A COOPERAÇÃO ENTRE OS ESTADOS MEMBROS DA CONFERÊNCIA DE MINISTROS DA JUSTIÇA DOS PAÍSES IBEROAMERICANOS EM MATÉRIA DE EQUIPES DE INVESTIGAÇÃO CONJUNTA

C - MARCO NORMATIVO ARMONIZADO

Proyecto de Armonización de la Legislación Penal en la Lucha contra el Crimen organizado en Centroamérica y República Dominicana

D- PROPOSTA DE PROTOCOLO DA CONVENÇÃO INTERAMERICANA SOBRE ASSISTÊNCIA MÚTUA EM MATÉRIA PENAL SOBRE EQUIPES CONJUNTAS DE INVESTIGAÇÃO 


\section{ACORDO QUADRO DE COOPERAÇÃO ENTRE OS \\ ESTADOS PARTES DO MERCOSUL E ESTADOS ASSOCIADOS PARA A CRIAÇÃO DE EQUIPES CONJUNTAS DE INVESTIGAÇÃO.}

A República Argentina, a República Federativa do Brasil, a República do Paraguai e a República Oriental do Uruguai, Estados Partes do MERCOSUL, e o Estado Plurinacional da Bolivia e a República do Equador, Estados Associados ao MERCOSUL, doravante denominados as Partes;

Recordando que a Convenção das Nações Unidas contra o Tráfico llícito de Entorpecentes e Substâncias Psicotrópicas (Convenção de Viena); a Convenção das Nações Unidas contra o Crime Organizado Transnacional (Convenção de Palermo) e seus Protocolos Adicionais; e a Convenção das Nações Unidas contra a Corrupção (Convenção de Mérida), já preveem a instrumentação de investigações conjuntas;

Preocupados com delitos como o tráfico ilícito de entorpecentes, a corrupção, a lavagem de ativos, o comércio de pessoas, o tráfico de migrantes, o tráfico de armas e todos aqueles que integram o chamado crime organizado transnacional, bem como os atos de terrorismo, ou delitos cujas características tornem necessária a atuação e o combate coordenados de mais de uma Parte;

Desejosos de reforçar a cooperação em matéria penal a fim de chegar a uma efetiva investigação de todas aquelas condutas referidas precedentemente;

Convencidos de que as equipes conjuntas de investigação constituirão uma ferramenta eficaz de cooperação internacional em matéria penal; e

Entendendo necessário contar com mecanismos apropriados de cooperação que permitam uma efetiva coordenação entre as autoridades das Partes.

\section{ACORDAM:}

\section{ARTIGO $1^{\circ}$}

\section{Âmbito}

As autoridades competentes de uma Parte, que estiverem a cargo de uma investigação penal, poderão solicitar a criação de uma Equipe Conjunta de Investigação às autoridades competentes de outra Parte, quando essa investigação tiver por objeto condutas delituosas que por suas características exijam a atuação coordenada de mais de uma Parte.

\section{ARTIGO $2^{\circ}$ \\ Faculdades}

A Equipe Conjunta de Investigação terá faculdades para atuar dentro dos territórios das Partes que as criaram, conforme a legislação interna das Partes onde estiver atuando a Equipe. 


\section{ARTIGO $3^{\circ}$ \\ Definições}

MERCOSUR

Para os fins do presente Acordo Quadro, entender-se-á por:

3.1. Equipe Conjunta de Investigação (ECl): É a constituída por meio de um instrumento de cooperação técnica específico que se celebra entre as Autoridades Competentes de duas ou mais Partes, para levar adiante investigações penais em seus territórios, por um tempo e fim determinados.

3.2 Instrumento de Cooperação Técnica: É o documento assinado entre as Autoridades Competentes, pelo qual se constitui uma ECl. Deverá conter os requisitos exigidos no presente Acordo Quadro.

3.3. Autoridades Competentes: São aquelas designadas em cada uma das Partes, conforme sua normativa interna, para propor a criação e para a respectiva aprovação de uma ECl.

3.4. Autoridade Central: É aquela designada por cada Parte, conforme sua legislação interna, para receber, analisar e transmitir as solicitações de constituição de uma ECl.

3.5. Integrantes da ECl: São os indicados no Instrumento de Cooperação Técnica, designados pelas Autoridades Competentes das Partes.

\section{ARTIGO $4^{\circ}$ Solicitação}

4.1 As solicitações de criação de uma $\mathrm{ECl}$ serão tramitadas através das Autoridades Centrais designadas por cada Parte, mediante o formulário que consta em Anexo e faz parte do presente Acordo.

4.2 Tais solicitações deverão conter:

a) A identificação da Parte Requerida;

b) A identificação das autoridades a cargo da investigação na Parte Requerente;

c) Uma exposição sucinta dos fatos e descrição dos motivos que justificam a necessidade da criação de uma $\mathrm{ECl}$;

d) As normas penais aplicáveis na Parte Requerente ao fato objeto da investigação;

e) A descrição dos procedimentos de investigação que se proponham realizar;

f) A identificação dos funcionários da Parte Requerente para a integração da $\mathrm{ECl}$;

g) O prazo estimado que demandará a atividade de investigação da $\mathrm{ECl}$; e

h) O projeto de Instrumento de Cooperação Técnica para consideração da Autoridade Competente da Parte Requerida. 

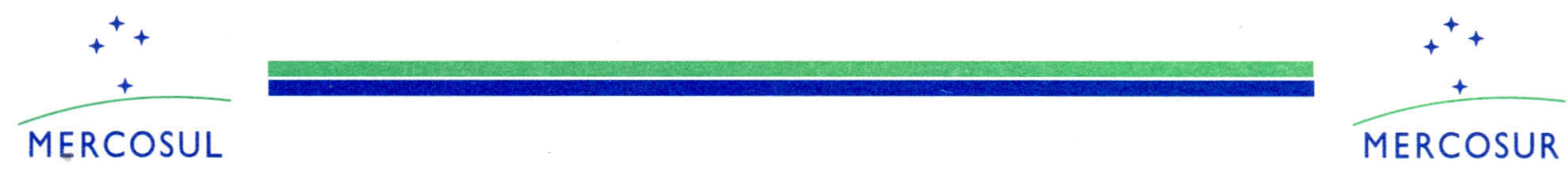

4.3 A solicitação deverá ser redigida no idioma da Parte Requerente e será acompanhada de uma tradução ao idioma da Parte Requerida, se for o caso.

\section{ARTIGO $5^{\circ}$ Tramitação}

Formalizada a solicitação pela Autoridade Competente da Parte Requerente, ela a remeterá a sua Autoridade Central. A Autoridade Central analisará se a solicitação reúne as condições estabelecidas no presente Acordo e, nesse caso, encaminhará o pedido à Autoridade Central da Parte Requerida.

A Autoridade Central da Parte Requerida, mediante prévio controle das condições do presente Acordo encaminhará, em seu caso, o pedido a sua Autoridade Competente a fim de que esta se pronuncie sobre a criação de uma $\mathrm{ECl}$, conforme sua legislação interna.

As Autoridades Centrais tramitarão as solicitações pelos meios mais expeditos e no menor prazo possível.

\section{ARTIGO $6^{\circ}$ \\ Aceitação}

A aceitação da criação de uma ECl será comunicada por meio das Autoridades Centrais, a fim de formalizar o Instrumento de Cooperação Técnica definitivo, que será assinado por ambas as Autoridades Competentes.

Na hipótese de a Autoridade Competente da Parte Requerida indeferir a solicitação de criação da $\mathrm{ECl}$, ela o comunicará a sua Autoridade Central, a qual, por sua vez, imediatamente o transmitirá à Autoridade Central da Parte Requerente. O indeferimento deverá ser sempre fundamentado.

\section{ARTIGO $7^{\circ}$ Instrumento de Cooperação Técnica}

7.1 O Instrumento de Cooperação Técnica deverá conter:

a) A identificação das Autoridades que assinam o Instrumento e dos Estados nos quais atuará a $\mathrm{ECl}$;

b) A finalidade específica e o prazo de funcionamento da $\mathrm{ECl}$;

c) A identificação do Chefe da Equipe pela Autoridade Competente do Estado no qual atue a ECl. Caso a Equipe atue em mais de um Estado, cada Parte identificará um Chefe de Equipe;

d) A identificação dos demais integrantes da $\mathrm{ECl}$, designados pelas Autoridades Competentes das Partes envolvidas;

e) As medidas ou procedimentos que será necessário realizar; 
f) Qualquer outra disposição especifica em matéria de funcionamento, organização

e logística que as Autoridades Competentes entendam necessária para o desenvolvimento eficaz da investigação;

7.2 O Instrumento de Cooperação Técnica deverá ser redigido, conforme o caso, nos idiomas das Partes Requerente e Requerida.

7.3 A finalidade específica do Instrumento de Cooperação Técnica, o prazo de funcionamento e as medidas ou procedimentos a realizar, poderão ser modificados por acordo das Autoridades Competentes.

\section{ARTIGO $8^{\circ}$ \\ Direção da Investigação}

O Chefe da Equipe terá amplas atribuições, no âmbito do objeto acordado, para desenhar os lineamentos da investigação e adotar as medidas que estimar pertinentes, consoante as normas de seu próprio Estado.

\section{ARTIGO $9^{\circ}$ \\ Responsabilidade}

A responsabilidade civil e penal pela atuação da $\mathrm{ECl}$ estará sujeita às normas do Estado de sua atuação. A responsabilidade administrativa estará determinada pela legislação da Parte à qual pertençam os integrantes da $\mathrm{ECl}$.

\section{ARTIGO 10 \\ Gastos da investigação}

Salvo acordo em contrário, os gastos decorrentes da investigação serão cobertos pela Parte Requerente, em tudo o que não for salários e retribuições pela atuação dos integrantes da $\mathrm{ECl}$ da Parte Requerida.

\section{ARTIGO 11 \\ Utilização da Prova e Informação}

A prova e a informação obtidas em virtude da atuação da $\mathrm{ECl}$ somente poderão ser utilizadas nas investigações que motivaram sua criação, salvo acordo em contrário das Autoridades Competentes.

As Autoridades Competentes poderão acordar que a informação e a prova obtidas, em virtude da atuação da $\mathrm{ECl}$, tenham caráter confidencial.

\section{ARTIGO 12} Isenção de legalização.

Os documentos que forem tramitados por intermédio das Autoridades Centrais, ficam dispensados de toda legalização ou outra formalidade análoga. 

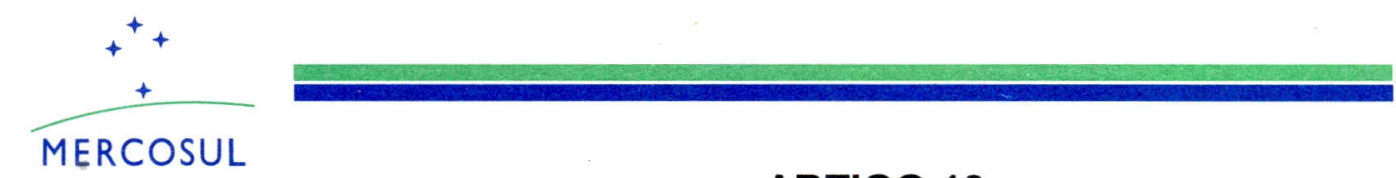

MERCOSUL

\section{ARTIGO 13}

\section{Autoridades Centrais}

As Partes, ao depositar o instrumento de ratificação do presente Acordo, comunicarão a designação da Autoridade Central ao Estado depositário, quem informará às demais Partes.

A Autoridade Central poderá ser alterada a qualquer momento, devendo a Parte comunicá-lo, no menor tempo possível, ao Estado depositário do presente Acordo, a fim de que informe as demais Partes da mudança efetuada.

\section{DISPOSIÇÕES FINAIS \\ ARTIGO 14 \\ Solução de Controvérsias}

As controvérsias que surgirem sobre a interpretação, a aplicação ou descumprimento das disposições contidas no presente Acordo entre os Estados Partes do MERCOSUL serão resolvidas pelo sistema de solução de controvérsias vigente no MERCOSUL.

As controvérsias que surgirem sobre a interpretação, a aplicação ou descumprimento das disposições contidas no presente Acordo entre um ou mais Estados Partes do MERCOSUL e um ou mais Estados Associados, bem como entre um ou mais Estados Associados serão resolvidas consoante o mecanismo de Solução de Controvérsias vigente entre as partes envolvidas no conflito.

\section{ARTIGO 15 \\ Vigência}

O presente Acordo entrará em vigor trinta (30) dias após o depósito do instrumento de ratificação pelo quarto Estado Parte do MERCOSUL. Na mesma data entrará em vigor para os Estados Associados que o tiverem ratificado anteriormente.

Para os Estados Associados que não o tiverem ratificado com anterioridade a essa data, o Acordo entrará em vigor no mesmo dia em que for depositado o respectivo instrumento de ratificação.

Os direitos e obrigações derivados do Acordo, somente serão aplicados aos Estados que o tiverem ratificado.

\section{ARTIGO 16 \\ Depósito}

A República do Paraguai será Depositária do presente Acordo e dos respectivos instrumentos de ratificação, devendo notificar às Partes as datas dos depósitos desses instrumentos e da entrada em vigor do Acordo, bem como enviar-lhes cópia devidamente autenticada do mesmo. 

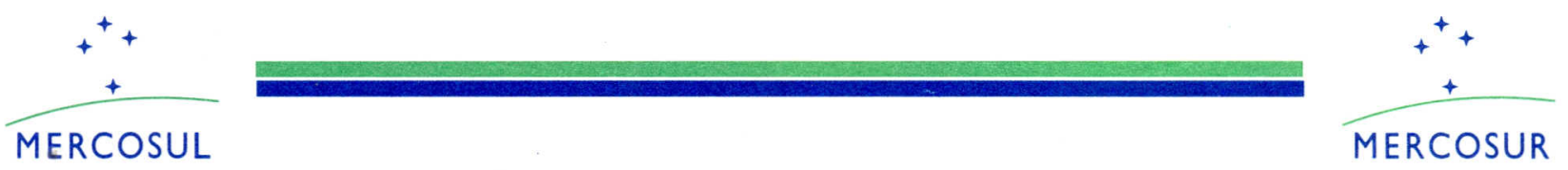

FEITO na cidade de San Juan, República Argentina, aos 2 dias do mês de agosto de 2010, em um original, nos idiomas espanhol e português, sendo ambos os textos igualmente autênticos.

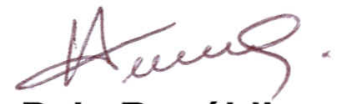

Pela República Argentina

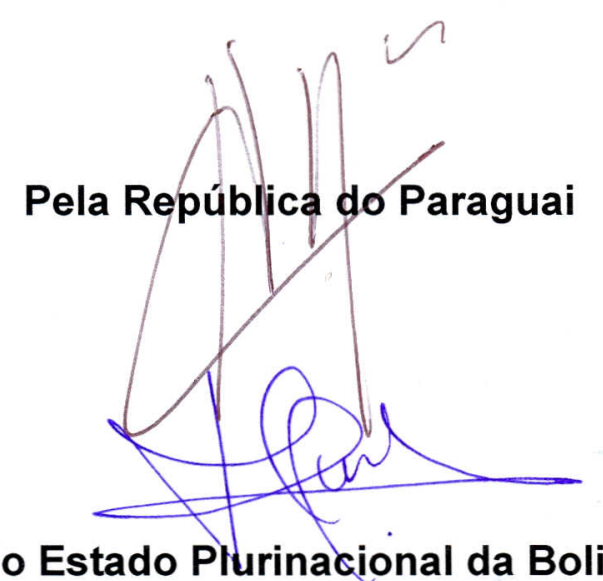

Pelo Estado Plurinacional da Bolivia

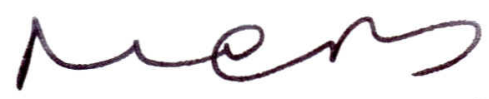

Pela República da Colômbia

Ad Refercudum
Pela República Federativa do Brasil

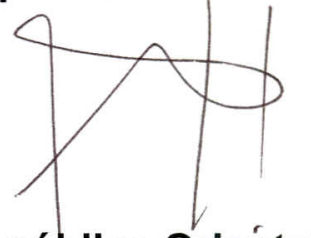

Pela República Oriental do Uruguai

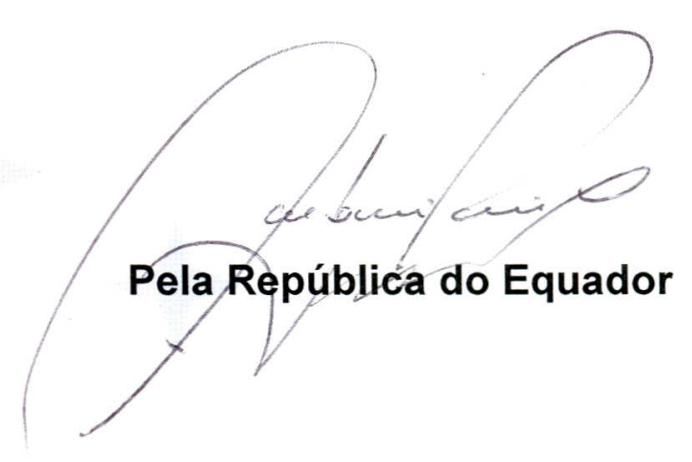

6 


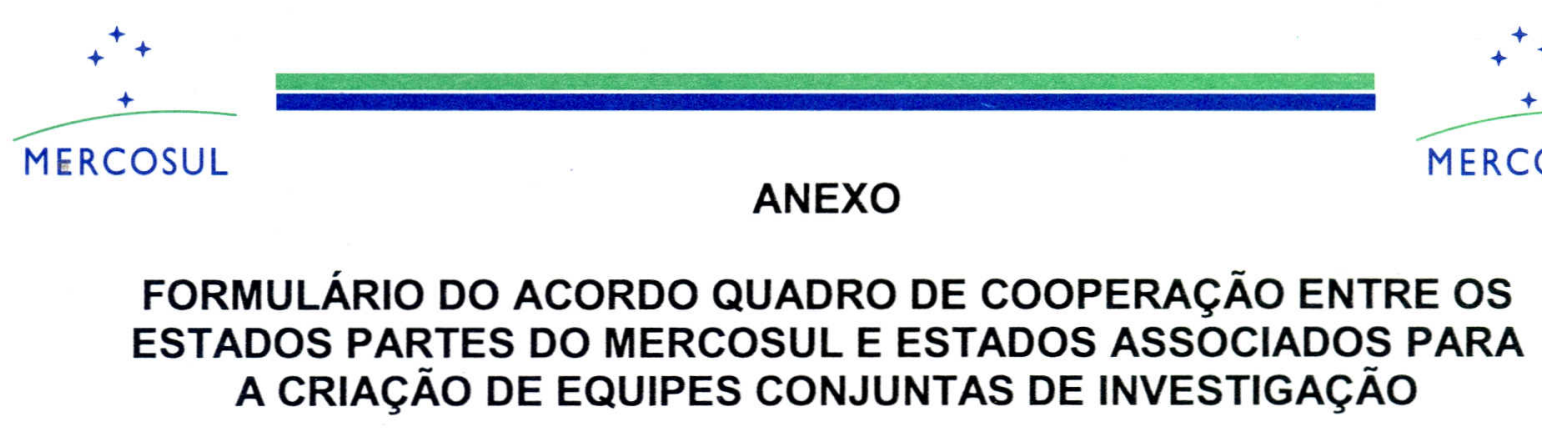

DE: ..(Autoridade Central da Parte Requerente)

PARA: .(Autoridade Central da Parte Requerida)

Em virtude do estabelecido no Acordo Quadro de Cooperação entre os Estados Partes do MERCOSUL e Estados Associados para a Criação de Equipes Conjuntas de Investigação, levamos ao conhecimento dessa Autoridade Central que a autoridade competente (identificação da autoridade competente) de....... (Parte Requerente) entendeu conveniente propor às autoridades competentes de seu país, a criação de uma EQUIPE CONJUNTA DE INVESTIGAÇÃO (ECI) no âmbito de um procedimento penal cujos detalhes são estabelecidos no presente formulário.

\section{A). Autoridade competente que requer a formação da $\mathrm{ECl}$ :}

(Dados da Autoridade Competente que requereu a criação da ECl, incluindo os dados de contato)

B) Procedimento penal no qual interessa a criação da ECl:

(Descrição sintética da causa incluindo os dados tendentes à identificação, fato investigado, normas aplicáveis, imputações, se couber, e, especialmente, conexões do caso com a Parte Requerida)

\section{C) Objetivos da ECl:}

(Finalidade da $\mathrm{ECl}$ no que diz respeito às informações, provas ou medidas que se deseja obter)

\section{D)Procedimentos de investigação a realizar pela ECl.}

......(Descrição de tais procedimentos)

\section{E) Funcionários que irão integrar a $\mathrm{ECl}$ pela Parte Requerente:}

(Nomes e dados de contato da totalidade dos funcionários que irão integrar a $\mathrm{ECl})$

F) Prazo de duração da $\mathrm{ECl}$ :

(Prazo estimado de atuação da ECl) 
MERCOSUL

Em virtude do estabelecido no Acordo Quadro de Cooperação entre os Estados Partes do MERCOSUL e Estados Associados para a Criação de Equipes Conjuntas de Investigação, a Autoridade Central de......... encaminha a solicitação da criação de uma $\mathrm{ECl}$ à Autoridade Central de nas condições que oportunamente serão acordadas no Instrumento de Cooperação Técnica, cujo projeto vai em anexo.

Em

aos

dias do mês de

de 
CONVENÇÃO PARA A COOPERAÇÃO ENTRE OS ESTADOS MEMBROS DA CONFERENCIA DE MINISTROS DA JUSTIÇA DOS PAÍSES IBEROAMERICANOS EM MATÉRIA DE EQUIPES DE INVESTIGAÇÃO CONJUNTA

Os Estados membros da Conferência de Ministros da Justiça dos Países Iberoamericanos (COMJIB), seguidamente designados «Partes»:

Atento o artigo $3 .^{\circ}$, alínea c), do Tratado constitutivo da Conferência de Ministros da Justiça dos Países Iberoamericanos, de 7 de outubro de 1992;

CONSCIENTES da necessidade de prevenir e lutar de forma conjunta, coordenada e diferenciada contra a criminalidade organizada transnacional e outras formas de criminalidade organizada que lhe está associada;

MANIFESTANDO a sua vontade em fortalecer e reforçar a cooperação no quadro regional e internacional na prevenção, investigação e perseguição da referida criminalidade;

ENTENDENDO que é necessário dispor de mecanismos modernos e eficazes que permitam enfrentar de forma célere a criminalidade transnacional;

TENDO EM CONTA a importância de utilizar técnicas especiais de investigação que permitam enfrentar de forma célere as diferentes modalidades que a criminalidade organizada transnacional assume no presente e aproveitando, também, os novos mecanismos e as modernas tecnologias;

SABENDO que uma perseguição coordenada da criminalidade pelos diferentes países requer uma aproximação e harmonização das legislações nacionais com a finalidade de tornar eficaz qualquer medida de cooperação judiciária ou policial;

TENDO PRESENTE o Acordo Quadro do MERCOSUl para a criação de Equipas Conjuntas de Investigação, feito em Buenos Aires em 2 de agosto de 2010, bem como a Decisão-Quadro da União Europeia de 13 de junho de 2002 e as diferentes legislações nacionais dos Estados membros da COMJIB;

SUBLINHANDO o clima de confiança mútua existente entre as Partes;

NO RESPEITO pelos princípios da soberania, igualdade e respeito mútuo;
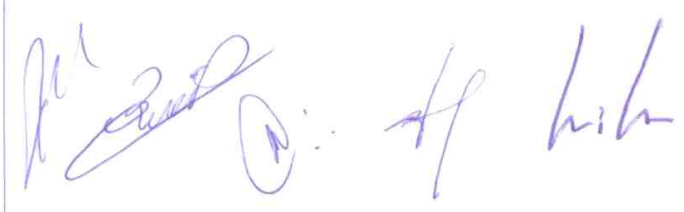


\section{ACORDAM:}

\section{Artigo 1. ${ }^{\circ}$ \\ Objeto}

A presente Convenção estabelece os requisitos e o regime jurídico aplicável à criação de Equipes de Investigação Conjunta (EIC) entre os Estados membros da COMJIB.

\section{Artigo 2. ${ }^{\circ}$ \\ Âmbito}

As Autoridades Competentes de uma ou de várias Partes encarregadas de uma investigação criminal podem solicitar a criação de uma EIC às Autoridades Competentes de outra ou de outras Partes, quando essa investigação tenha por objeto condutas ilícitas que, pelas suas características, requerem a atuação coordenada de mais do que uma Parte.

\section{Artigo 3. ${ }^{\circ}$ \\ Capacidade}

A EIC tem capacidade para desenvolver as suas investigações criminais no interior do território das Partes que a criaram, em conformidade com a legislação interna das Partes onde a EIC se encontrar a atuar.

\section{Artigo $4 .^{\circ}$ \\ Definições}

Para os fins da presente Convenção entende-se por:

4.1. Equipa de Investigação Conjunta: é a equipa constituída através de um Instrumento de Cooperação Técnica específico celebrado pelas Autoridades Competentes de duas ou mais Partes, para realizar investigações penais nos seus territórios por um tempo e finalidade determinados, com o propósito de reunir provas para um processo.

4.2. Instrumento de Cooperação Técnica: é o documento subscrito entre as Autoridades Competentes das Partes através do qual se constitui a EIC, e que deve incorporar os requisitos estabelecidos na presente Convenção.

4.3. Autoridade Competente: é a autoridade designada pelas Partes para propor a criação e a aprovação de uma EIC.

4.4. Autoridade Central: é a autoridade designada pelas Partes para receber, analisar e transmitir os pedidos de constituição de uma EIC.

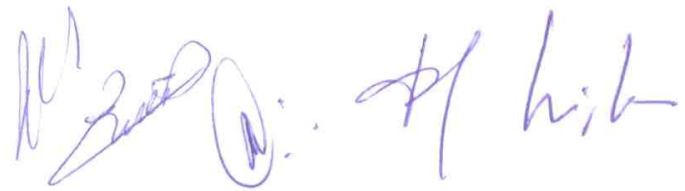




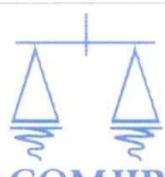

\section{COMJIB}

Com o objetivo de conferir maior agilidade ao processo de constituição das EIC, as Partes podem unificar a Autoridade Central e a Autoridade Competente.

4.5. Integrantes da $\boldsymbol{E I C}$ : são as pessoas designadas no Instrumento de Cooperação Técnica pelas Autoridades Competentes das Partes.

4.6. Participantes na EIC: são as pessoas que, além das integrantes da EIC, intervêm na mesma na qualidade e com as atribuições que sejam determinadas pelas Partes. Podem ser originárias não apenas das Partes nesta Convenção mas também de organismos internacionais ou de países terceiros.

4.7. Investigação criminal: é a investigação realizada com a finalidade de reunir os elementos de prova que conduzam ao esclarecimento dos presumíveis factos ilícitos, o objeto dos mesmos, a identificação dos seus autores, a localização dos meios e instrumentos dos mesmos, dos bens, produtos e vantagens resultantes do ilícito, bem como qualquer outro indício útil para a fundamentação da ação penal.

\section{Artigo 5. \\ Pedido}

5.1. Os pedidos para a criação de uma EIC são efetuados através da Autoridade Central de uma Parte e enviados à Autoridade Central de uma ou de outras Partes, mediante o formulário constante do Anexo I, que constitui parte integrante da presente Convenção.

\subsection{Os pedidos devem conter:}

a) A identificação da ou das Partes convidadas a fazer parte da EIC;

b) A identificação das Autoridades Competentes encarregadas da investigação na Parte solicitante;

c) Uma exposição sucinta dos factos e a descrição dos motivos que justificam a necessidade de criação de uma EIC;

d) As normas penais aplicáveis no Estado de onde é originário o pedido aos factos objeto da investigação;

e) A descrição dos procedimentos de investigação que se pretendem realizar;

f) A identificação das pessoas designadas pela Parte solicitante que são propostas para integrar a EIC;

g) A identificação dos participantes na EIC;

h) O prazo estimado para as atividades de investigação da EIC; e

i) O projeto de Instrumento de Cooperação Técnica para ser apreciado pela Autoridade Competente das Partes convidadas para a constituição da EIC.

5.3. Os pedidos para a criação de uma EIC devem ser redigidos na língua da Parte solicitante, que os deve traduzir para a língua da Parte convidada apenas no caso em que esta última o solicitar.
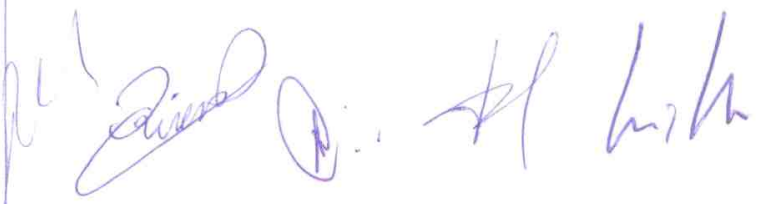


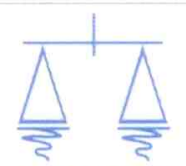

\section{COMJIB}

\section{Artigo 6. ${ }^{\circ}$}

Processo

6.1. O pedido de criação de uma EIC é enviado pela Parte solicitante às outras Partes através da sua Autoridade Central.

6.2. Previamente ao envio do pedido à Autoridade Central da Parte concreta, a Autoridade Central da Parte solicitante verifica se foram cumpridas as condições estabelecidas na presente Convenção.

6.3. Os pedidos para a criação de uma EIC devem ser transmitidos através de meios expeditos e seguros que assegurem a confidencialidade e permitam verificar a receção dos mesmos pelas outras Partes.

\section{Artigo $7 .^{\circ}$ \\ Aceitação}

7.1. A aceitação da criação de uma EIC é comunicada através das Autoridades Centrais, a fim de ser formalizado o Instrumento de Cooperação Técnica definitivo.

7.2. O Instrumento de Cooperação Técnica é subscrito pelas Autoridades Competentes das Partes ou por quem for indicado para o efeito pelas referidas Autoridades.

7.3. As Autoridades Competentes das Partes podem delegar nas suas Autoridades Centrais a autorização para apresentar o pedido de criação de uma EIC ou para a sua recusa.

\section{Artigo 8. ${ }^{\circ}$ \\ Recusa}

8.1. Se a Autoridade Competente da Parte convidada recusar o pedido para a criação da EIC deve comunicar essa recusa à sua Autoridade Central que, por sua vez, a deve transmitir imediatamente à Autoridade Central da Parte Solicitante.

8.2. A recusa deve ser sempre fundamentada e comunicada à outra Parte no mais curto período de tempo, com as salvaguardas a que se refere o $\mathrm{n}^{\circ} 3$ do artigo $6 .^{\circ}$ da presente Convenção.

\section{Artigo 9. ${ }^{\circ}$}

\section{Instrumento de Cooperação Téenica}

9.1 O Instrumento de Cooperação Técnica deve conter:

a) A identificação das Autoridades que subscrevem o Instrumento e das Partes onde atue a EIC.

b) A finalidade específica da EIC;

c) O prazo de funcionamento da EIC;
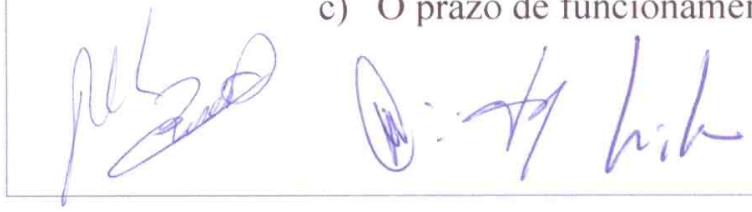


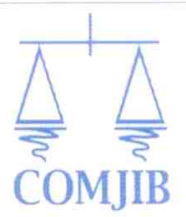

d) A identificação do Chefe da Equipa pela Autoridade Competente do Estado onde atue a EIC; no caso de a EIC atuar em mais do que um Estado, cada Parte deve identificar um Chefe de Equipa;

e) A identificação dos integrantes da EIC designados pelas Autoridades Competentes das Partes envolvidas;

f) A identificação dos participantes na EIC, bem como a sua função, objetivos, obrigações e responsabilidades;

g) As medidas ou procedimentos que seja necessário realizar;

h) Qualquer outra disposição específica em matéria de funcionamento e de logística que as Partes entendam necessária para o desenvolvimento eficaz da investigação.

9.2. O Instrumento de Cooperação Técnica deve ser redigido, em cada caso concreto, nas línguas oficiais de todas as Partes integrantes da EIC.

9.3 A finalidade específica do Instrumento de Cooperação Técnica, o prazo de funcionamento e as medidas ou procedimentos a realizar podem ser modificados por acordo entre as Partes.

\section{Artigo 10. ${ }^{\circ}$}

\section{Direção da investigação}

A direção da investigação é da competência dos Chefes de Equipa designados no Instrumento de Cooperação Técnica, a quem são reconhecidas as competências necessárias para delinear as linhas de investigação, realizar diligências e adotar as medidas que considerem pertinentes em conformidade com as disposições de direito processual penal do seu próprio Estado, que é aquele onde a EIC se encontra a atuar.

\section{Artigo 11.}

\section{Incorporação de funcionários alheios às Partes}

11.1. As Partes podem acordar a qualquer momento a incorporação na EIC de integrantes de Estados alheios aos que criaram a Equipa ou de organismos internacionais.

11.2. Salvo acordo em contrario, os integrantes referidos no número anterior não gozam dos direitos concedidos aos membros da equipa ou destinados a integrá-la.

\section{Artigo 12. ${ }^{\circ}$ \\ Responsabilidade}

12.1. A responsabilidade civil e penal pelas atuações realizadas pelos membros ou pelos participantes na EIC está sujeita às disposições do Estado onde se desenvolva a sua atuação.

12.2. A responsabilidade administrativa é regida pela legislação da Parte ou dos organismos a que pertencem os integrantes e os participantes na EIC.

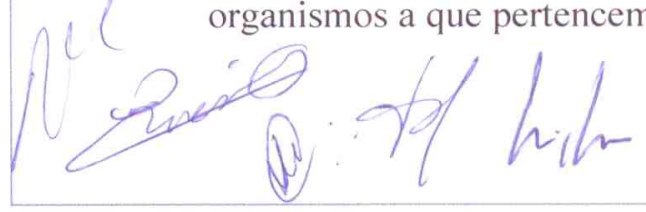




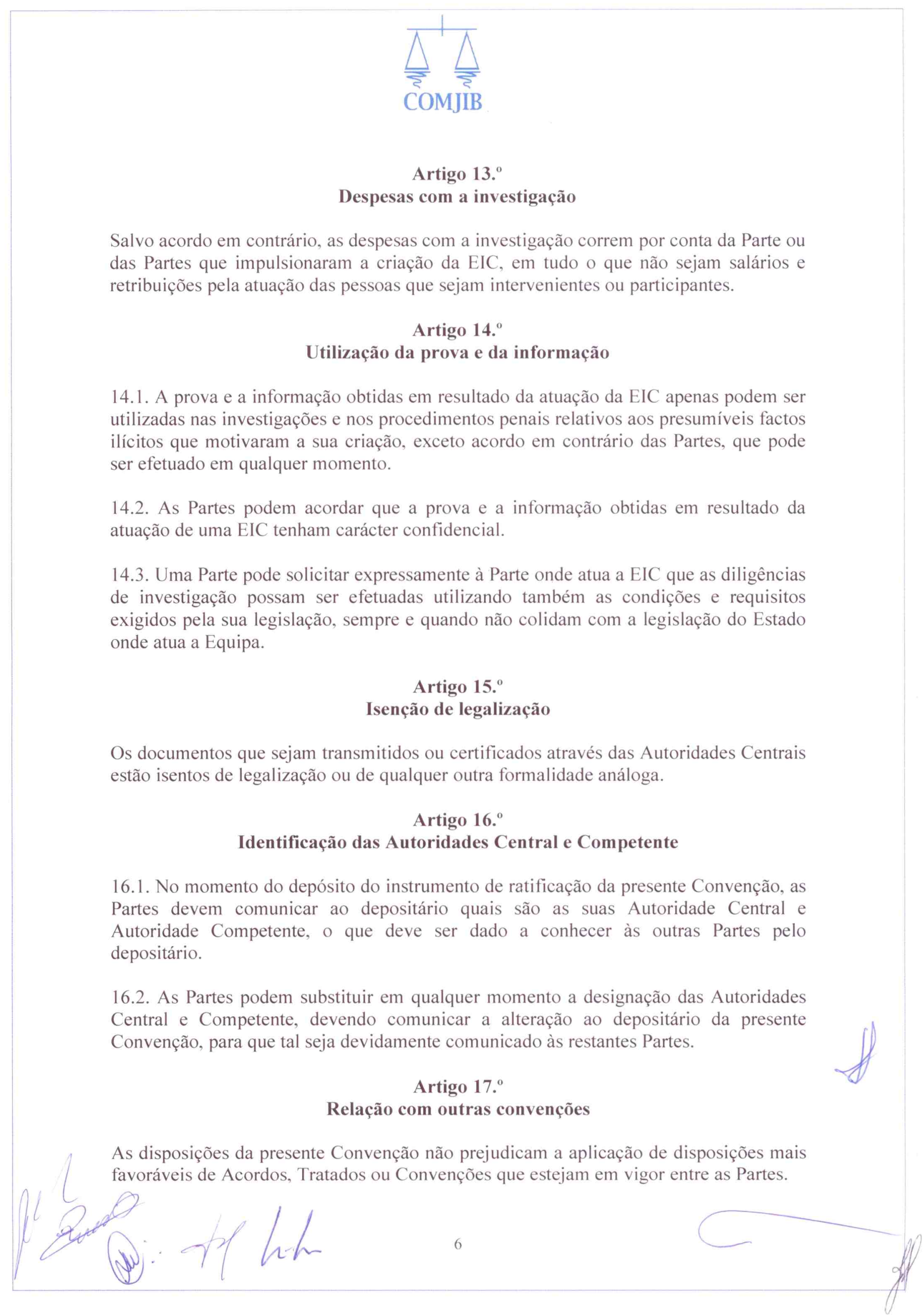




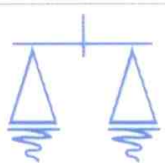

\section{COMJIB}

\section{Artigo 18. ${ }^{\circ}$ \\ Solução de controvérsias}

As controvérsias que surjam sobre o alcance, a interpretação ou a aplicação das disposições da presente Convenção são resolvidas através de consultas diretas entre as Autoridades Centrais ou, caso não seja possível, pela via diplomática.

\section{Artigo 19.}

\section{Entrada em vigor}

19.1. A presente Convenção entra em vigor trinta dias após a data em que tenha sido depositado o terceiro instrumento de ratificação.

19.2. Para cada Estado que ratifique ou adira à mesma depois de ter sido depositado o terceiro instrumento de ratificação, a Convenção entrará em vigor trinta dias após a data em que esse Estado tenha depositado o seu instrumento de ratificação ou de adesão.

\section{Artículo 20. ${ }^{\circ}$ \\ Emendas}

20.1. A presente Convenção pode ser objeto de emendas por solicitação de qualquer das Partes.

20.2. As emendas são aprovadas por acordo entre todas as Partes.

20.3. As emendas entram em vigor de acordo com o disposto no Artigo $19 .^{\circ}$ da presente Convenção.

\section{Artigo 21. ${ }^{\circ}$ \\ Reservas}

21.1. As Partes podem, no momento da assinatura da presente Convenção ou do depósito do seu instrumento de ratificação, formular reservas relativamente a uma ou várias disposições da mesma.

21.2. Qualquer Parte que tiver formulado uma reserva compromete-se a retirar essa reserva logo que as circunstâncias o permitam.

21.3. A retirada de reservas deve ser feita através de notificação dirigida ao SecretárioGeral da COMJIB, o qual comunicará imediatamente esse facto a todas as Partes na Convenção.

21.4. A Parte que tenha formulado uma reserva relativamente a uma disposição da Convenção não pode pretender a aplicação dessa disposição por outra Parte mais do que na medida em que ela própria a tivesse aceite.

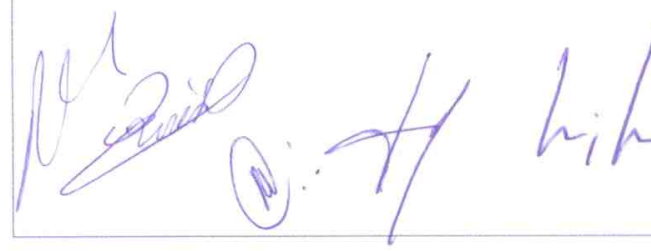




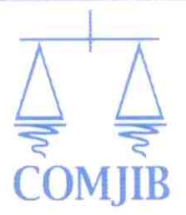

21.5. As reservas entram em vigor de acordo com o disposto no artigo $19 .^{\circ}$ da presente Convenção.

\section{Artigo 22. \\ Denúncia}

22.1. A presente Convenção vigora por tempo indeterminado.

22.2. Qualquer Parte pode denunciar a presente Convenção a todo o momento através de notificação por escrito dirigida ao depositário, o qual o deve comunicar às restantes Partes.

22.3. A denúncia produz efeitos cento e oitenta dias depois da referida notificação.

22.4. Sem prejuízo do disposto no número anterior, a presente Convenção continua a aplicar-se aos pedidos existentes à data da receção da notificação da denúncia que estejam em curso até à conclusão da respetiva execução.

\section{Artigo 23. ${ }^{\circ}$ \\ Deposito}

23.1. O Secretário-Geral da Conferência de Ministros da Justiça dos Países Iberoamericanos (COMJIB) é o depositário da presente Convenção e dos respetivos instrumentos de ratificação, devendo notificar as Partes da data do depósito desses instrumentos e da entrada em vigor da Convenção, bem como enviar-lhes uma cópia devidamente autenticada da mesma.

\subsection{A mesma regra é aplicável relativamente às emendas e reservas.}

23.3. O depositário da Convenção disponibiliza também os meios necessários para receber e transmitir às Partes neste instrumento as experiências existentes relativamente à aplicação do mesmo.

Assinado em Viña del Mar no dia 5 de abril de 2013, em dois originais, um em língua espanhola e outro em língua portuguesa, sendo ambos os textos igualmente autênticos.

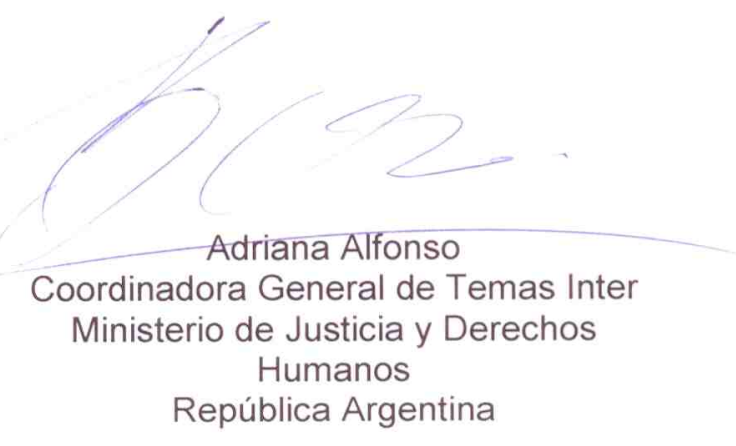

8

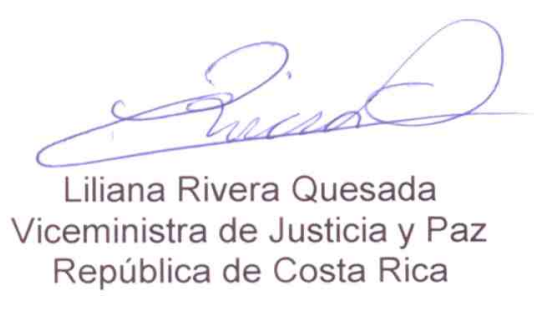

Liliana Rivera Quesada

iceministra de Justicia y Paz
República de Costa Rica 


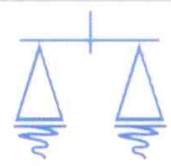

COMJIB
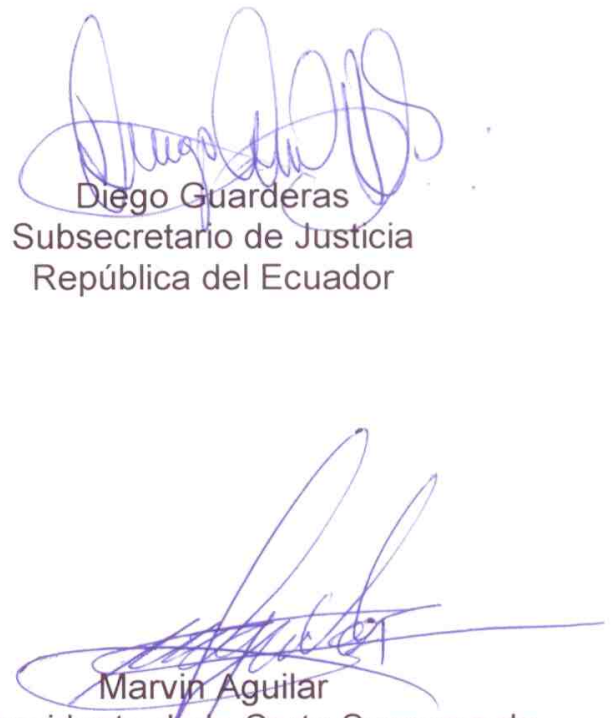

Vice-Presidente de/a Corte Suprema de pusticia

Repúblila de Nicaragua<smiles>C1CCCCC1</smiles>

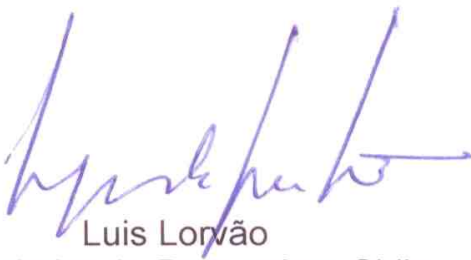

Embajador de Portugal en Chile

República de Portugal
Douglas Mautricio Moreno Viceministro de Justicia y Seguridad Pública

República de EI Salvador
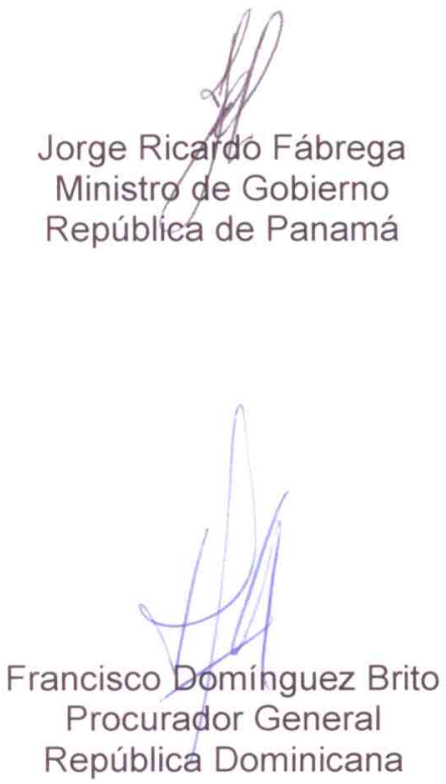


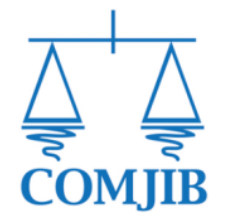

\section{MARCO NORMATIVO ARMONIZADO}

Proyecto de Armonización de la Legislación Penal en la Lucha contra el Crimen Organizado en Centroamérica y República Dominicana 


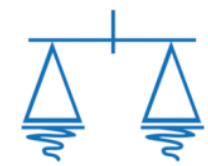

COMJIB
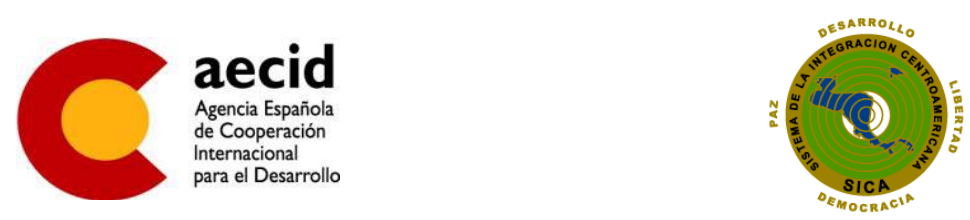

\section{Índice}

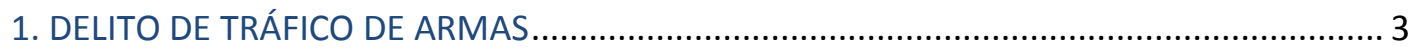

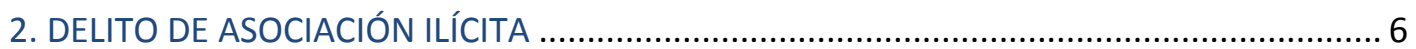

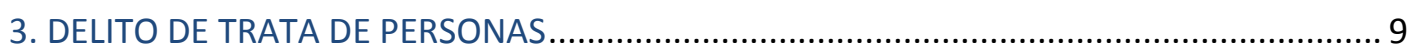

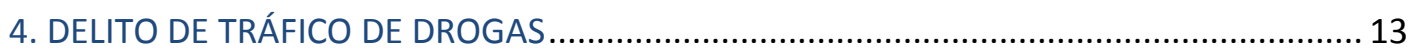

5. REGULACIÓN DE LA RESPONSABILIDAD PENAL DE LAS PERSONAS JURÍDICAS ............... 17

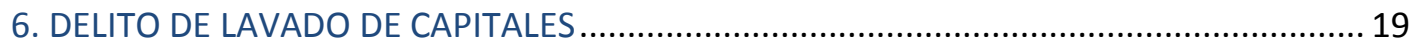

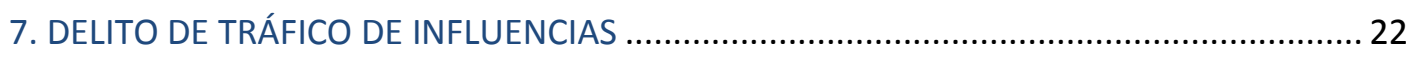

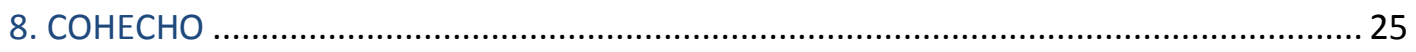

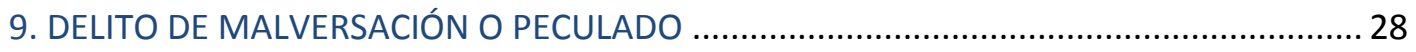

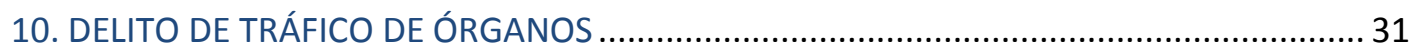

11. PROPUESTA DE TRATADO INTERNACIONAL A CELEBRAR EN EL ÁMBITO DEL SISTEMA DE INTEGRACIÓN CENTROAMERICANO (SICA) RELATIVO A LA ORDEN DE DETENCIÓN Y A LOS PROCEDIMIENTOS DE ENTREGA ENTRE LOS ESTADOS MIEMBROS.............................. 34

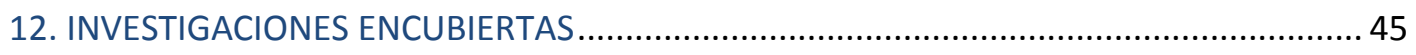

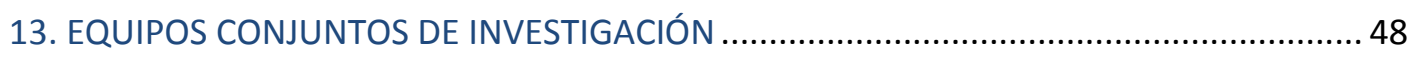

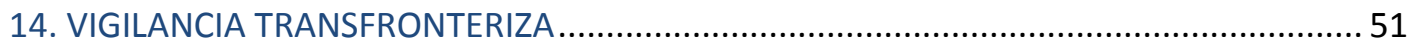

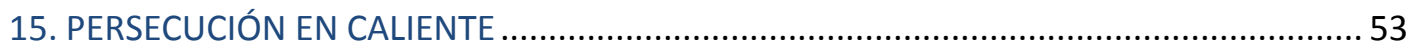

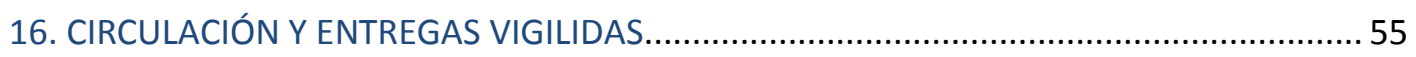

17. MEDIDAS DE PROTECCIÓN VÍCTIMAS, TESTIGOS Y PERITOS ....................................... 58

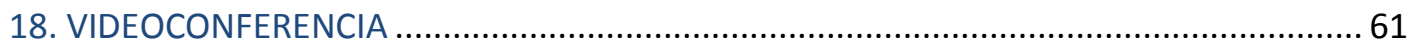

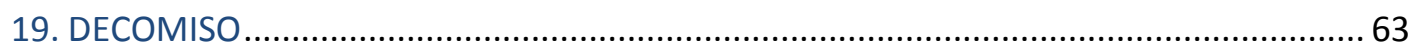

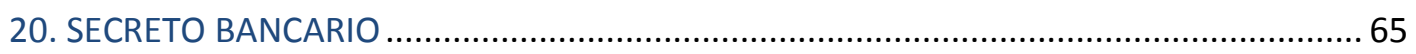

21. UNIDAD DE INFORMACIÓN CRIMINAL Y TRANSFERENCIA DE PRUEBAS ......................67

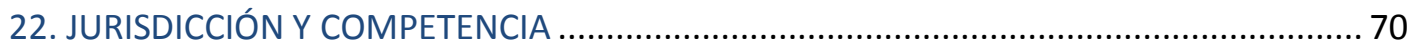

23. NUEVOS MÉTODOS DE INVESTIGACIÓN Y PRUEBA CIENTÍFICA..................................... 73

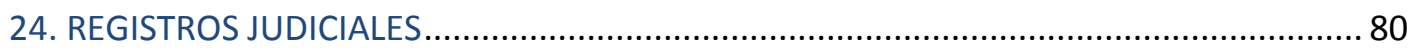

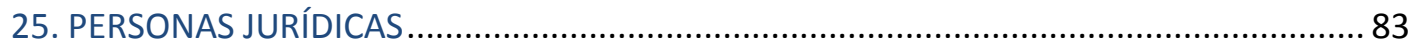



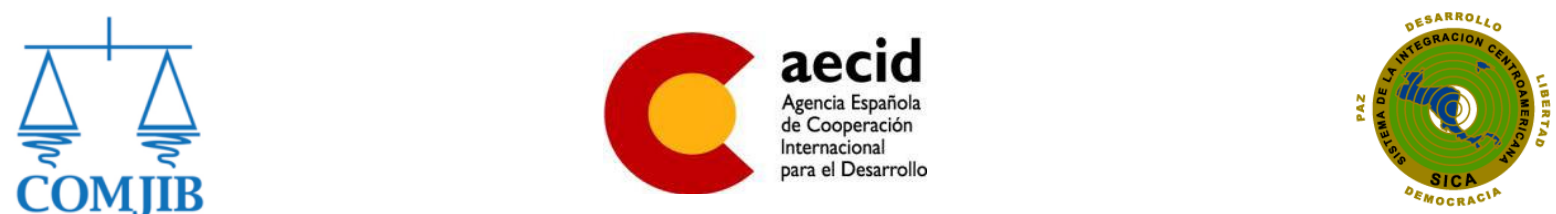

\section{EQUIPOS CONJUNTOS DE INVESTIGACIÓN}

Definición legal ECI

- Primer Criterio: Las autoridades competentes de dos o más Estados parte del SICA y asociados podrán crear de común acuerdo un equipo conjunto de investigación, con un fin determinado y por un período limitado que podrá ampliarse con el consentimiento de todas las partes, para llevar a cabo investigaciones penales en uno o más de los Estados que hayan creado el equipo. La composición del equipo se determinará en el acuerdo de constitución del mismo.

Ámbito de aplicación

- Segundo Criterio: Podrán crearse equipos conjuntos de investigación, en particular, en los casos siguientes: i) cuando la investigación de infracciones penales en un Estado parte requiera investigaciones que impliquen también a otros Estados parte; y ii) cuando varios Estados parte realicen investigaciones sobre infracciones penales que, debido a las circunstancias del caso, requieran una actuación coordinada y concertada. Cualquiera de los Estados afectados podrá formular una solicitud de creación de un equipo conjunto de investigación.

Constitución del ECl

- Tercer Criterio: El equipo se creará en uno de los Estados en los que se prevea efectuar la investigación. El Acuerdo de constitución, además de las indicaciones derivadas de los apartados anteriores, incluirá: i) voluntad explícita de constitución del equipo; ii) motivación suficiente de su necesidad y tiempo máximo de vigencia del equipo; iii) objeto y fines de la investigación; iv) composición del equipo; v) legislación aplicable; vi) medidas organizativas y competencias del jefe del equipo; y vii) régimen de la utilización de la información obtenida.

Condiciones de actuación

- Cuarto Criterio: El equipo conjunto de investigación actuará en el territorio de los Estados que lo hayan creado, con arreglo a las condiciones generales siguientes: i) dirigirá el equipo un representante de la autoridad competente del Estado en el que actúe el equipo. El jefe del equipo actuará dentro de los límites de las competencias que tenga atribuidas con arreglo a la legislación nacional; ii) el Estado en el que actúe el equipo tomará las disposiciones organizativas necesarias; iii) el equipo actuará de conformidad con la legislación del Estado en el que se estén llevando a cabo las investigaciones, teniendo en cuenta las condiciones establecidas en el acuerdo de constitución del equipo; iv) el jefe del equipo organizará la investigación, y podrá encomendar actuaciones concretas a los miembros del equipo; v) cuando sea necesario adoptar medidas de investigación en el territorio de uno de los Estados parte, los miembros nacionales del equipo 

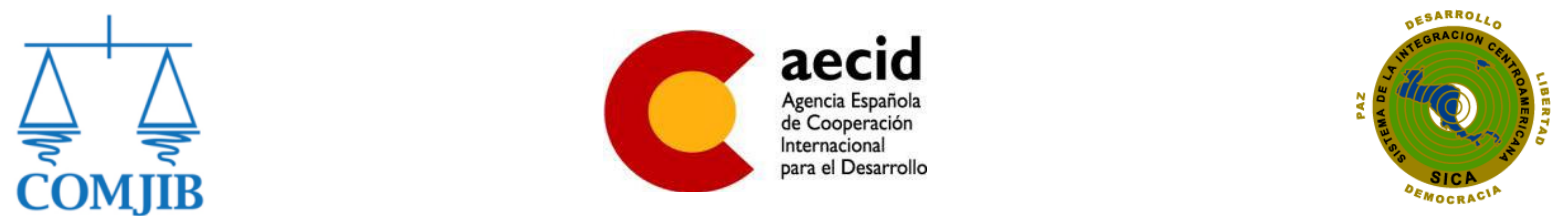

podrán pedir a sus propias autoridades que adopten tales medidas en las mismas condiciones que si fueran solicitadas en el marco de una investigación nacional; y vi) si es necesaria la adopción de medidas o la petición de ayuda a un Estado que no haya participado en la creación del equipo, las autoridades competentes del Estado en el que actúe el equipo se encargarán de formular la petición.

- Quinto Criterio: En el caso de que varíen las circunstancias que motivaron la investigación, se determinará la forma de valorar la posibilidad de extenderla a hechos que guarden conexión directa con el objeto del acuerdo, o ampliar el período por el cual fue inicialmente acordada, con el consentimiento de todos los Estados que constituyeron el equipo, sin necesidad de otro acuerdo expreso.

- Sexto Criterio: Se deberá prever en qué modo puede, atendiendo a las circunstancias, modificarse la composición del equipo. Dicha modificación podrá incluir personas que no sean representantes de los Estados miembros, en cuyo caso no gozarán de los derechos concedidos a los miembros del equipo, salvo acuerdo en contrario.

Informaciones obtenidas durante la actuación conjunta

- Séptimo Criterio: La información que obtenga el equipo conjunto de investigación podrá utilizarse para los fines siguientes: i) para los que se haya creado el equipo; ii) para descubrir, investigar y enjuiciar otras infracciones penales, condicionada a la autorización previa del Estado en que se haya obtenido la información. Dicha autorización podrá denegarse únicamente cuando se ponga en peligro las investigaciones penales en el Estado parte de que se trate o cuando dicho Estado pueda denegar la asistencia judicial; iii) para evitar una amenaza inmediata y grave para la seguridad pública; y iv) para otros fines, siempre y cuando hayan convenido en ello los Estados que crearon el equipo.

Responsabilidad de los integrantes del ECI

- Octavo Criterio: Durante las operaciones desarrolladas por el ECI, los integrantes del equipo procedentes de un Estado que no sea aquel en el que se desarrolla la operación, se asimilarán a los miembros de seguridad de este último Estado en lo relativo a las infracciones que pudieran sufrir o cometer.

- Noveno Criterio: En el ejercicio de las actividades propias de la investigación, los miembros destinados estarán sujetos al mismo régimen de responsabilidad patrimonial que los miembros de seguridad del Estado en que se realizan las actividades.

- Décimo Criterio: El Estado en cuyo territorio se causaren daños y perjuicios asumirá la reparación de los mismos en las condiciones aplicables a los daños y perjuicios causados por sus propios integrantes del equipo, salvo en los supuestos de fuerza mayor. 


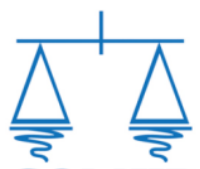

COMJIB

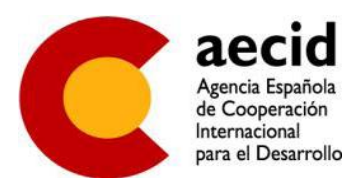

- Undécimo Criterio: El Estado parte cuyos funcionarios hubieren causado daños y perjuicios a cualquier persona en el territorio de otro Estado restituirá íntegramente a este último los importes que hubiere abonado a las víctimas o a sus derechohabientes. 


$\begin{array}{cl}\text { REUNIÕES DE MINISTROS DA JUSTIÇA OU } & \text { OEA/Ser.K/XXXIV } \\ \text { DE OUTROS MINISTROS OU PROCURADORES-GERAIS } & \text { PENAL/doc.39/14 } \\ \text { DAS AMÉRICAS } & 1 \text { maio } 2014 \\ & \text { Original: espanhol }\end{array}$

Sexta Reunião do Grupo de Trabalho sobre Cooperação Jurídica em Matéria Penal

15 e 16 de maio de 2014

Brasília, Brasil

\section{PROPOSTA DE \\ PROTOCOLO DA CONVENÇÃO INTERAMERICANA SOBRE ASSISTÊNCIA MÚTUA EM MATÉRIA PENAL SOBRE EQUIPES CONJUNTAS DE INVESTIGAÇÃO*}

\section{APRESENTAÇÃO}

Na Quinta Reunião do Grupo de Trabalho sobre Cooperação Jurídica em Matéria Penal, bem como na Nona Reunião de Ministros da Justiça ou Outros Ministros ou Procuradores-Gerais das Américas (REMJA-IX), os Estados membros encarregaram o mencionado Grupo de Trabalho de avançar "...na consideração de um documento com diretrizes jurídicas que sirvam de modelo aos Estados que o necessitem, para acordar a criação de equipes conjuntas de investigação, com base em proposta elaborada e apresentada pelo Grupo de Trabalho liderado pela Delegação do Chile e constituído, ademais, pelas delegações do Brasil, Guatemala, Jamaica, Peru, Suriname e Uruguai, em sua Sexta Reunião, levando em conta, no que seja pertinente, o Acordo-Quadro de Cooperação entre os Estados Partes no MERCOSUL e Estados Associados para a Criação de Equipes Conjuntas de Investigação".

Com base no acima exposto, a Delegação do Chile elaborou o presente documento destinado a complementar a Convenção Interamericana sobre Assistência Mútua em Matéria Penal, de 1992, que reúne os elementos essenciais que, a juízo dessa delegação, deviam ter constado de uma regulamentação dessa matéria, levando em conta, entre outros, os seguintes documentos e instrumentos:

- No âmbito das REMJA, as Recomendações da Quinta Reunião do Grupo de Trabalho sobre Cooperação Jurídica em Matéria Penal;

- No âmbito da COMJIB, o Acordo-Quadro de Cooperação entre os Estados Partes no MERCOSUL e Estados Associados para a Criação de Equipes Conjuntas de Investigação;

- Lei 11/2003, de 21 de maio, que regulamenta as Equipes Conjuntas de Investigação Penal no Âmbito da União Europeia;

- Decisão-Quadro do Conselho da Europa, de 13 de junho de 2012, sobre Equipes Conjuntas de Investigação (2002/465/JAI);

- Convenção das Nações Unidas contra o Tráfico Ilícito de Entorpecentes e Substâncias Psicotrópicas, de 1988;

- Convenção das Nações Unidas contra o Crime Organizado Transnacional, de 2000, e seus Protocolos Adicionais; e

- Convenção das Nações Unidas contra a Corrupção.

\footnotetext{
* O presente documento foi elaborado pela Delegação do Chile, levando em conta as recomendações I.2 da Quinta Reunião do Grupo de Trabalho (documento PENAL/doc.34/12 rev. 1) e III.3, d), da REMJA IX (documento REMJA-IX/doc.2/12 rev. 1).
} 


\section{PROPOSTA DE \\ PROTOCOLO DA CONVENÇÃO INTERAMERICANA SOBRE ASSISTÊNCIA MÚTUA EM MATÉRIA PENAL SOBRE EQUIPES CONJUNTAS DE INVESTIGAÇÃO}

\section{PREÂMBULO}

Os Estados Partes no presente Protocolo,

DECLARANDO que alguns crimes como o tráfico ilícito de entorpecentes, a corrupção, a lavagem de ativos, o tráfico de pessoas, o tráfico de migrantes, o tráfico de armas, o terrorismo e, em geral, os que constituem a denominada "criminalidade organizada transnacional" exigem uma ação conjunta e coordenada das autoridades encarregadas da investigação penal;

PREOCUPADOS porque, na ausência de um instrumento dessa natureza, não é possível concretizar uma investigação penal eficiente e conjunta em dois ou mais Estados;

RECORDANDO que as Equipes Conjuntas de Investigação são expressamente contempladas na Convenção das Nações Unidas contra o Tráfico Ilícito de Entorpecentes e Substâncias Psicotrópicas (Convenção de Viena); na Convenção das Nações Unidas contra o Crime Organizado Transnacional (Convenção de Palermo) e seus Protocolos Adicionais; e na Convenção das Nações Unidas contra a Corrupção (Convenção de Mérida); e

CONVENCIDOS de que é útil complementar a Convenção Interamericana sobre Assistência Mútua em Matéria Penal, com o objetivo de regulamentar especificamente as Equipes Conjuntas de Investigação,

\section{ACORDAM O SEGUINTE:}

\section{ARTIGO I \\ DEFINIÇÕES}

Para efeitos do presente Protocolo se entenderá por:

1.- Equipe conjunta de investigação (ECI):

É a constituída por um instrumento específico acordado entre as Autoridades Competentes de duas ou mais Partes para conduzir investigações penais nos respectivos territórios, por um tempo e para fins determinados.

\section{2.- Autoridade Central:}

É a designada por um Estado Parte para receber, analisar e encaminhar os pedidos de constituição de uma ECI.

\section{3.- Autoridade Competente:}

É a designada pela legislação de um Estado Parte para solicitar, verificar e designar os integrantes de uma ECI.

4.- Pedido de assistência internacional para a criação de uma ECI: 
É o pedido formal apresentado pela Autoridade Competente de um Estado Parte para a criação de uma Equipe Conjunta de Investigação.

5.- Acordo de constituição de uma ECI:

É o ato jurídico mediante o qual as Autoridades Competentes de dois ou mais Estados regulamentam a constituição, organização e funcionamento de uma Equipe Conjunta de Investigação.

\section{ARTIGO II \\ ÂMBITO DE APLICAÇÃO}

As Autoridades Competentes de um Estado Parte que conduzam uma investigação penal poderão solicitar às Autoridades Competentes de outro ou outros Estados Partes a criação de uma Equipe Conjunta de Investigação, quando o crime investigado exija a ação coordenada e concertada de todas elas.

\section{ARTIGO III \\ DIREITO APLICÁVEL}

A Equipe Conjunta de Investigação poderá atuar no território de cada um dos Estados Partes que a tenham criado.

As faculdades, impedimentos e obrigações dos integrantes da ECI, bem como sua atuação, estarão sujeitas à lei do Estado em que atuem.

A responsabilidade civil e penal pela atuação da ECI estará sujeita às normas do Estado em que atue. A responsabilidade administrativa será determinada pela legislação da Parte a que pertençam os integrantes da ECI.

O Chefe ou os Chefes da Equipe conduzirão a investigação e atuação da ECI em conformidade com a lei do Estado em que esta atue.

\section{ARTIGO IV \\ PEDIDO DE ASSISTÊNCIA INTERNACIONAL PARA A CRIAÇÃO DE UMA ECI}

Os pedidos de assistência internacional cujo objeto seja a criação de uma ECI conterão as seguintes informações:

a) Identificação da Parte ou das Partes Requeridas;

b) Identificação das autoridades encarregadas da investigação na Parte Requerente;

c) Crime a que se refere o processo e descrição sumária dos fatos que o constituem, investigação ou ação penal de que se trate e descrição dos fatos a que se refere o pedido;

d) Descrição dos motivos que justifiquem a necessidade de criação de uma ECI;

e) Normas penais aplicáveis na Parte Requerente ao fato objeto da investigação;

f) Descrição dos procedimentos necessários à condução da investigação; 
g) Identificação dos funcionários da Parte Requerente propostos para integrar a ECI;

h) Prazo estimado necessário à atividade de investigação da ECI; e

i) Minuta do Acordo de Constituição da ECI para consideração da Autoridade Competente da Parte Requerida.

Os pedidos e Acordos de Constituição de uma ECI, bem como a documentação que figure em anexo, serão traduzidos para o idioma oficial do Estado requerido.

\section{ARTIGO V \\ PROCEDIMENTO}

A Autoridade Competente que formule um pedido de assistência internacional para a criação de uma ECI deverá enviá-lo à Autoridade Central respectiva, a qual, após analisá-lo conforme as normas do presente Protocolo, o remeterá sem delonga à Autoridade Central da Parte ou das Partes Requeridas, que, por sua vez, após a verificação das condições do Acordo de Constituição, o encaminhará, caso seja pertinente, à Autoridade Competente respectiva, a fim de que a ele dê o devido andamento, de acordo com a legislação interna.

A aceitação ou recusa da criação de uma ECI será comunicada à Autoridade Requerente por meio das Autoridades Centrais, a fim de que, caso seja pertinente, se proceda à negociação e assinatura do Acordo de Constituição pelas Autoridades Competentes.

\section{ARTIGO VI \\ ACORDO DE CONSTITUIÇÃO DA ECI}

O Acordo de Constituição da ECI fará menção pelo menos aos seguintes itens:

a) Identificação das Autoridades Competentes que assinam o Acordo;

b) Identificação do Estado ou dos Estados em que atuará a ECI;

c) Objetivo específico e prazo de funcionamento da ECI;

d) Individualização do Chefe da Equipe designado pelas Autoridades Competentes do Estado em que atuará a ECI;

e) Relação dos demais integrantes da ECI;

f) Procedimento de atuação e diligências a serem adotadas pela ECI;

g) Qualquer outra disposição específica em matéria de funcionamento, organização e logística, que as Autoridades Competentes entendam necessária para o desempenho eficiente da ECI.

De comum acordo, as Autoridades Competentes poderão modificar, complementar ou tornar sem efeito o Acordo de Constituição. 


\section{ARTIGO VII \\ UTILIZAÇÃO DA PROVA E DAS INFORMAÇÕES}

As provas e informações obtidas em virtude da atuação da ECI só poderão ser usadas nas investigações que motivaram sua criação, salvo acordo em contrário das Autoridades Competentes.

Caso seja necessário, as Autoridades Competentes poderão acordar que as informações ou provas obtidas ou apresentadas pela ECI tenham caráter confidencial.

\section{ARTIGO VIII \\ CAUSAS DE INDEFERIMENTO}

O Estado Requerido poderá indeferir o pedido de assistência internacional para a criação de uma ECI, observando as causas dispostas no artigo $9^{\circ}$ da Convenção Interamericana sobre Assistência Mútua em Matéria Penal.

\section{ARTIGO IX \\ GASTOS}

O Estado requerido se encarregará de todos os gastos ordinários de funcionamento da Equipe Conjunta dentro de seu território, com exceção dos seguintes, que serão custeados pelo Estado Requerente:

a) Honorários de peritos; e

b) Despesas conexas de viagem provenientes do transporte de pessoas do território de um Estado para o do outro.

Caso se afigure que a tramitação do pedido possa ocasionar custos extraordinários, os Estados Partes manterão consultas para determinar os termos e condições mediante os quais a assistência poderia ser prestada.

\section{ARTICULO X \\ ISENÇÃO DE LEGALIZAÇÃO}

Os documentos que venham a tramitar por meio das Autoridades Centrais, de acordo com este Protocolo, serão dispensados de legalização ou autenticação.

\section{ARTIGO XI ASSINATURA E DEPÓSITO}

O presente Protocolo estará aberto à assinatura dos Estados membros da Organização dos Estados Americanos.

O presente Protocolo estará sujeito a ratificação e adesão. Os instrumentos de ratificação e adesão serão depositados na Secretaria-Geral da Organização dos Estados Americanos.

Feito na cidade de aos , dias do mês de de 20 